\title{
Calypso as a vehicle for political commentary: An endangered musical species
}

by

\section{Darryl Dean}

A thesis submitted to the Faculty of Graduate and Postdoctoral Affairs in partial fulfillment of the requirements for the degree of

Master of Journalism

School of Journalism and Communication

\author{
Carleton University \\ Ottawa, Ontario
}

Supervisor: Professor Christopher Waddell

(C) 2015

Darryl Dean 


\begin{abstract}
Calypso, widely regarded today (in 2015) as the national music of the two-island Caribbean state of Trinidad and Tobago, was born out of the struggle in the 18th century of enslaved Africans in Trinidad to maintain their cultural traditions. The music of the slaves was banned by the colonial authorities and after emancipation in the 19th century, their songs, many with biting, satirical lyrics and political and social commentary, were subject to repressive censorship laws.
\end{abstract}

Although official censorship of calypso is no longer in effect in Trinidad and Tobago, this musical genre continues to face major challenges. As more aficionados of the art form turn to soca, the more popular "jump up" or party music which developed from calypso, unofficial censorship and self-censorship as well as other factors impact negatively on this genre, raising concerns for its survival as a vehicle for political commentary. 


\section{ACKNOWLEDGEMENTS}

I would like to thank my supervisor, Christopher Waddell, for his guidance throughout the process of researching and writing this thesis. Professor Waddell's suggestions and queries often reminded me that I was dealing with a subject, aspects of which were unfamiliar to many outside the homeland of calypso. Hence the need for clarifications and explanations of various issues that are quite well known and understood in the calypso community.

I also wish to thank Professor Susan Harada with whom I made initial contact when I decided, after many years, to finish the work I had started at Carleton University towards the Master of Journalism degree. Professor Harada provided me with useful advice about the course work and made helpful suggestions after reading my thesis proposal and early drafts of sections of the thesis.

My thanks also go to Professor Fred Fletcher of York University in Toronto for his valuable advice as my instructor in courses dealing directly with the research for my thesis. Also, my thanks to several calypsonians, academics and others whom I have interviewed. Their knowledge and insights about calypso have been of vital importance in examining the current state of the art form as a vehicle for political commentary.

I wish to make special mention of Mr. George Maharaj of Toronto who, with his vast knowledge of calypso, has been very helpful in providing answers to many questions at a moment's notice. I also wish to place on record my thanks to His Excellency Anthony Thomas Aquinas Carmona, President of the Republic of Trinidad and Tobago, known in the calypso world as Prophet of 
Sisyphus, and Mr. Basdeo Panday, a former prime minister of Trinidad and Tobago, for interviews granted to me while I was researching this thesis. 


\section{TABLE OF CONTENTS}

ABSTRACT

ACKNOWLEDGEMENTS $\quad$ ii

TABLE OF CONTENTS

CHAPTER ONE

Introduction

Research Questions

Methodology

Literature

CHAPTER TWO

Roots of Calypso

CHAPTER THREE

Banning and Censorship

CHAPTER FOUR

From Colonialism to Independence and Beyond

CHAPTER FIVE

Identity, Race and Gender

CHAPTER SIX

Unofficial Censorship and Self-Censorship

CHAPTER SEVEN

The Mighty Sparrow (Slinger Francisco)

CHAPTER EIGHT

Chalkdust (Hollis Liverpool)

CHAPTER NINE

Black Stalin (Leroy Calliste)

CHAPTER TEN

Gypsy (Winston Peters)

CHAPTER ELEVEN 
Calypso Rose (McCartha Linda Sandy-Lewis) 97

CHAPTER TWELVE 102

Denyse Plummer

CHAPTER THIRTEEN

David Rudder 107

CHAPTER FOURTEEN

Prophet of Sisyphus (President Anthony Carmona) 112

CHAPTER FIFTEEN

Calypsonians vs. calypso singers $\quad 117$

CHAPTER SIXTEEN 126

Conclusion

$\begin{array}{ll}\text { REFERENCES } & 138\end{array}$

$\begin{array}{ll}\text { APPENDIX } & 143\end{array}$ 


\section{Chapter One}

\section{INTRODUCTION}

Calypso, widely regarded as the national music of the two-island Caribbean state of Trinidad and Tobago, originated among enslaved Africans in Trinidad who started arriving in island during the second half of the 18th century. Despite strict controls placed on their activities, the slaves who were brought to work on the agricultural estates, sought to keep alive their cultural traditions which included songs with biting, satirical lyrics. It was out of their struggle to maintain their traditions in song and dance while under the influence of other musical forms - such as French and Spanish - which existed in the island, that calypso developed as a vehicle for social and political commentary. However, long after slavery ended in Trinidad, this musical genre continues to face major challenges to its survival as a vehicle for political commentary - the main focus of this study.

Tracing the evolution of calypso from its origins in the period of slavery in colonial Trinidad (between the1780s and the1830s) to its development since Trinidad and Tobago became independent in 1962, this thesis will examine the challenges to the art form posed by restraints to freedom of expression and other factors. It will argue that although censorship of calypso under Trinidad and Tobago's Theatres and Dance Halls Ordinance ended in 1951, in the current post-independence period the art form faces major problems of what this thesis calls unofficial censorship as well as self-censorship. So as calypso continues to evolve and with the greater demand for soca, the popular fast-paced "jump up" music which itself developed from calypso, independent political commentary in the art form remains an endangered musical species. 
This thesis will further argue that if there were a golden age of political commentary in calypso in Trinidad and Tobago, it was in the colonial period - specifically, the time when censorship of calypso under the Theatres and Dance Halls Ordinance was in effect (1934-51). During that time, calypsonians defied the authorities in their bid to deliver their "editorials in song" and their creative talents blossomed in spite of the harsh environment of official restraint.

Quo vadis, calypso? With the evolution of calypso, a study of some important aspects of the current state of the art form would make a useful contribution to the literature of this musical genre in the 21 st century 


\section{RESEARCH QUESTIONS}

Fundamental questions about the development of calypso will be addressed. What are the origins of this musical genre? How did it become a vehicle for political commentary? How did calypsonians deal with the problems of censorship in the colonial period in Trinidad in order to keep their music alive? Are calypsonians in Trinidad and Tobago enjoying greater freedom of expression since the country became independent? How effective is calypso today in 2015 as a vehicle for political commentary?

This thesis will also address issues of identity, race and gender. What role does calypso play in the construction of a national identity in Trinidad and Tobago? In a multicultural society in which negative racial stereotypes have been prominent, has calypso been divisive in its treatment of race? How serious has been the problem of the denigration of women in calypso? Are there noticeable changes in the treatment of race and gender in calypso today?

At this time when there are three daily newspapers, more than half a dozen television stations and more than 30 radio stations in Trinidad and Tobago, along with proliferating social media, what impact do the "editorials in song" of the calypsonians have on public opinion in the country? As the music continues to evolve, how serious are the current problems of unofficial censorship and self-censorship? And how are they affecting freedom of expression in rhythm and rhyme? 


\section{METHODOLOGY}

Interviews were conducted with 15 calypsonians, some of them former calypso monarchs, as well as academics whose writings about calypso have distinguished them as leading researchers in this area of study. The main purpose of the interviews was to obtain from the respondents their assessment of the challenges facing calypso as a vehicle for political commentary.

The respondents were specifically asked to comment on the future of calypso in view of the increasing demand for soca, the "jump up" music which developed from calypso and is gaining international popularity. They were also asked to comment on the growing problem of unofficial censorship and self-censorship with government funding of calypso tents and competitions and the hiring of calypsonians to sing at political events and in radio and television commercials for political parties.

Questions dealing with race and gender in Trinidad and Tobago's multicultural society were also addressed in the interviews with specific reference to the treatment in calypso of women and people of Indian descent, comprising about 40-per cent of the country's population of about 1.3-million.

Respondents were also asked about the effectiveness of political commentary in calypso on public opinion in Trinidad and Tobago at the present time when there is a vibrant press and a proliferating social media in the country. 
Calypsonians who were interviewed are from different geographic areas in Trinidad. Many of them live outside of Trinidad and Tobago's capital city of Port of Spain which is aptly described as the calypso capital of the world - the city where the annual calypso monarch competition is held and where the main calypso tents are located. Three of the interviewees live outside of Trinidad and Tobago - one in Canada and two in the United States. Four are women.

Also interviewed were the president of the Republic of Trinidad and Tobago who was a semi-finalist in the calypso monarch competition in the two-island state in 1980, a former prime minister of Trinidad and Tobago and two academics who live in Trinidad and whose works are valuable sources of information.

All the interviews were conducted by telephone.

In addition, 30 letters were sent by e-mail to persons with specialized knowledge of various aspects of calypso or matters related to the art form. The letters sought information about some specific issues, which are addressed in this thesis. Replies were received from most of the persons to whom letters were sent. 


\section{LITERATURE}

Calypso was born out of the struggle among enslaved Africans in Trinidad in the $18^{\text {th }}$ century to maintain their cultural traditions in song and dance. It became a vehicle for political and social commentary but faced major challenges posed by restraints to freedom of expression during the period of slavery (between the 1780s and the1830s) and after emancipation. With the evolution of calypso in the post-independence period in Trinidad and Tobago, new musical forms developed, among them, the now more popular soca. This thesis argues that calypso, despite its historical importance, faces a struggle for its own survival as a vehicle for political commentary and has thus become an endangered musical species.

Several scholarly works provide valuable information about the origins of calypso and its development from the period of African slavery in colonial Trinidad to post-independence in the two-island state of Trinidad and Tobago. Of these, the most important work concerning the history of the art form is J. D. Elder's $1966 \mathrm{PhD}$ dissertation (University of Pennsylvania), Evolution of the Traditional Calypso in Trinidad and Tobago: A socio-historical analysis of song change. This study of the structure, style and content of calypso spans a period of more than a hundred years (1850-1960). However, since 1960, new musical forms developed from calypso. One of them - soca - which became the favourite music of calypso aficionados at parties and dances, developed in the 1970s.

Two major works dealing with the Trinidad carnival also discuss the origins and development of calypso which became the music of the carnival. They are Rituals of Power and Rebellion: The Carnival Tradition in Trinidad and Tobago 1763-1962, by Hollis Liverpool, a university lecturer and prominent calypsonian and The Trinidad Carnival: Mandate for a 
National Theatre, by Errol Hill, a playwright who taught drama and theatre in the United States, Nigeria and the West Indies.

Both books are important studies about a major festival. However, Liverpool's work, published in 2001 and based on his $1993 \mathrm{PhD}$ thesis (University of Michigan), is more wideranging in its treatment of the subject and includes some historical material contained in Hill's book, published more than 20 years before his (Liverpool's) own work.

These two works, along with Elder's dissertation, provide an important foundation for the research in this thesis dealing with the roots of calypso.

Five other works (three books and two articles) are also significant sources of information concerning the genesis of the art form, as discussed in chapter two of this thesis. The books are Kaiso! The Trinidad Calypso: A study of calypso as oral literature, by Keith Q. Warner, Professor Emeritus of French and Caribbean Studies at George Mason University in Virginia, Race Relations in Colonial Trinidad, by Bridget Brereton. a history professor at the University of the West Indies and Calypso from France to Trinidad : 800 Years of History, by calypsonian Raphael de Leon (The Roaring Lion). The articles, written by British sociologist Andrew Pearse, are from Caribbean Quarterly, a peer-reviewed journal of the University of the West Indies.

While several researchers cited in this thesis acknowledge the African roots of calypso, de Leon argues that the art form is of French origin and has no links with Africa. His denial of its African links is difficult to sustain in view of the historical evidence to the contrary.

Nevertheless, his book is especially useful for the information it provides about the development 
of the art form as well as for the pen portraits of calypsonians of the colonial past and the lyrics of old calypsos, many of which are not familiar to present-day followers.

This thesis also argues that if there were a golden age of political commentary in calypso in Trinidad and Tobago, it was during the colonial period when censorship was in effect. In its discussion of banning, censorship and other restraints to calypso in chapter three, this thesis returns to the works of Liverpool and Elder which provide historical details about the repressive laws which existed during the time of slavery and after emancipation.

Two other works also make important contributions to this discussion. They are Calypso \& Society in Pre-Independence Trinidad by Gordon Rohlehr, a former professor of West Indian literature at the University of the West Indies and Atilla's Kaiso: a short history of Trinidad calypso by calypsonian Raymond Quevedo (Atilla the Hun).

Rohlehr says that censorship under the Theatres and Dance Halls Ordinance, in effect from 1934 to 1951, did not put a stop to the composition of political calypsos but that "calypsoes continued to flourish during the period." (Rohlehr 1990: 294) He also notes that calypsonians "resented and resisted even the legitimate authority of the Police, often refusing to submit the texts of calypsoes for scrutiny before singing them in the tents..." (Rohlehr 1999:295)

Quevedo who, as a calypsonian and manager of a calypso tent, had first-hand experience of the effects of censorship, recounts the struggle to keep the art form alive. His book tells of his own fight in the legislative council of Trinidad and Tobago of which he became an elected member, against the repressive measures of the Theatres and Dance Halls Ordinance. Taken together, these sources provide a good account of the development of calypso in the preindependence period. 
Chapter four which traces the development of calypso from 1956 to the postindependence period, draws on the work of Louis Regis, a lecturer at the University of Trinidad and Tobago. His book, The Political Calypso: True Opposition in Trinidad and Tobago 1962-87, developed from his Master's thesis on popular music as communication, discusses changes in the relationship between calypsonians and government. Noting that in any study of calypso, the primary resource remains the calypso text itself, Regis reviews scores of lyrics from 1956 until 1986 when the People's National Movement (PNM) government which had been in power for three decades, was voted out of office. From his review emerges a colourful history of the country's transition from colonialism to independence and of developments in the early years of independence.

In chapter five, we examine several works that explore issues of identity, race and gender. One of them, The Caribbean Postcolonial: Social Equality, Post-Nationalism and Cultural Hybridity, by Shalini Puri, an associate professor of English at the University of Pittsburgh, discusses the "cultural centrality " of calypso in Trinidad and the relations between Indo- and Afro-Trinidadians, the two larger racial groups in the country.

Puri presents a good description of the hindrances to the development of a national culture in Trinidad and Tobago. Noting that calypso and carnival are perceived to be "expressions of Afro-Trinidadian culture, "her book, developed from a doctoral dissertation, poses a pertinent question in respect to identity and race: "What does it suggest about the place of Indo-Trinidadians in the national imaginary that calypso has been seen as simultaneously Afro-Trinidadian and national ?" (Puri 2004: 183) 
Another work which also deals with the issue of race in Trinidad and Tobago is Tassa, Chutney \& Soca: The East Indian Contribution to the Calypso by Zeno Obiageli Constance, a calypso researcher, playwright and retired teacher. This study is replete with verses that tell the story of relations - sometimes antagonistic - between people of African and Indian descent in Trinidad and Tobago. It also discusses the positive contribution which Indo-Trinidadians hav emade to the art form which is still widely perceived as exclusively an expression of AfroTrinidadian culture.

Two other books - Governing Sound:The Cultural Politics of Trinidad 's Carnival Musics, by Jocelyne Guilbault, a university professor in the department of music at the University of Califonia, Berkeley and Bacchanalian Sentiments, by Kevin Birth, an associate professor of anthropology at Queens College, City University of New York - also make significant contributions to the discussion of identity, race and gender.

Among the most important primary sources quoted in this thesis are the texts of calypso ranging from the colonial period to the twenty-first century. Several of them written in the postindependence period are used, along with information obtained from interviews with calypsonians and academics and reports from Trinidad newspapers, to support the argument that calypso as a vehicle for political commentary is an endangered species.

All in all, the books and articles previously cited in the literature review provide valuable information about the origins and development of the art form and related issues of identity, race and gender. However, this thesis relies on more up-to-date sources in examining the current issues of unofficial censorship and self-censorship, both of which impact negatively on calypso 
as a vehicle for political commentary (See chapter six) and the controversial calypsonians versus calypso singers debate. (See chapter fifteen) Newspaper reports and interviews with calypsonians are vital sources of information with respect to these issues which are yet to be fully explored in the literature of this musical genre. However, to better understand the development of calypso, let us first look at the genesis of the art form as discussed in the following chapter. 


\section{Chapter Two}

\section{ROOTS OF CALYPSO}

People are interested

To know where calypso originated.

Some say it came from Cuba

Some say British Guiana

Some contend seriously

It was sung by Moses crossing the Red Sea.

I told them' No, no, oh no

Trinidad is the land of calypso.'

An excerpt from Land of Calypso, a composition by The Roaring Lion (Raphael de Leon)

To understand the origins of calypso, it is necessary to examine the history of Trinidad and Tobago and its social and political development. Its history under colonial rule goes back to the 15 th century though calypso, in its earliest form, originated among enslaved Africans in Trinidad in the 18th century. As J. D. Elder notes in his study of the evolution of the traditional calypso of Trinidad and Tobago:

The history of the Trinidad Negroes' struggle for personal freedom from slavery and of their progress to political and national independence cannot be extricated from the history of the traditional calypso which has become a national song. (Elder 1966: 83).

Trinidad and the smaller island of Tobago were both sighted by Christopher Columbus in 1498 on his third voyage to the New World and claimed for the Spanish crown. While Tobago changed hands among European nations more than 30 times, Trinidad remained a Spanish possession for about 300 years until it was surrendered to Britain in 1797. Trinidad and Tobago were linked together as a British colony in 1889. 
Under Spanish rule, Trinidad had remained a relatively underdeveloped colony untilthe 18th century when the king of Spain issued a Cedula (Decree) of Population which granted Spaniards and foreigners of the Catholic faith the right to settle in Spanish colonies and to receive land grants. French-speaking planters from other islands in the Caribbean took advantage of the liberal settlement laws.

By 1783, they had started arriving in Trinidad with their African slaves. ${ }^{1}$ They also brought to the island the carnival - an annual pre-lenten festival which, anthropologist Andrew Pearse writes, was marked by elaborate masked balls and other activities which included houseto-house visits, street promenading, the playing of music and dancing and a variety of frolics. (Pearse 1956:180)

Participation in the carnival was then confined exclusively to what was described as "the upper class of the community." (Pearse 1956: 180) Meanwhile, on the plantations, the slaves sought to maintain their African traditions in song and dance, despite laws which made it illegal for them to play their musical instruments and assemble for music-making and dancing.

We had to chant and sing to express our feelings

To that wicked and cruel man.

That was the only medicine to get them to listen

And it's so calypso began.

An excerpt from The Slave, a calypso by the Mighty Sparrow (Slinger Francisco)

Calypsonian and university lecturer Hollis "Chalkdust" Liverpool explains that to help withstand their everyday problems, the enslaved Africans "turned to and developed the

\footnotetext{
${ }^{1}$ Also among the new arrivals in the island were free coloured people from Haiti and other French-speaking areas of the Caribbean as well as people of French citizenship who had fled from France.
} 
Calypso." He notes that it encompassed "all the African cultural traits relating to music:

percussive rhythmic beats, the call-and-response pattern, extemporaneous singing and satire."

(Liverpool 2001: 185). Quoting Errol Hill, the playwright and university lecturer, Liverpool also notes that "the antecedents of calypso were the praise songs and songs of derision of West African natives captured as slaves and brought to the West Indies." (Hill 1972, quoted in Liverpool 2001: 186)

Gros Jean is generally considered to have been the first calypsonian. He was appointed "Mait Caiso" (Master of Kaiso ${ }^{2}$ ) by his master, Pierre Begorrat, a planter who came to Trinidad from the neighbouring island of Martinique in 1784.

The "Mait Caiso" and other African slaves entertained Begorrat on his estate with their singing. In the "griot tradition of West Africa, "these singers who were known as chauntuelles, ${ }^{3}$ ridiculed his (Begorrat's) enemies and flattered his friends, according to Liverpool who explains that by using flattery, Gros Jean allowed Begorrat to see himself "in the manner he wanted the public to see him; impressive, powerful, merciless, brutal." (Liverpool 2001: 19293). For example, Gros Jean sang the following lines about his master:

Begorrat et Diab'la, c'est un

Begorrat et Diab'la, c'est deux

Begorrat fort, cruel et mauvais

Begorrat roi-la-dans son pays.

\footnotetext{
${ }^{2}$ According to the Dictionary of the English/Creole of Trinidad and Tobago, the term kaiso means calypso, especially with serious social commentary as the subject. The term is also used as a exclamation of admiration or appreciation for calypso.

${ }^{3}$ Derived from the French, a 'chanterelle,' a chauntuelle or chantwell is a singer, usually of calypso in its earliest form. The term also appears in the literature as chantwell, shantwell, chantwelle and chantuel.
} 
(Begorrat and the devil are one

Begorrat and the devil are a pair

Begorrat strong, cruel and wicked

Begorrat king in his country.)

There is little biographical information about Gros Jean as compared with that of the calypso monarchs of the 20th and 21st centuries. However, according to calypso researcher Sampson, Gros Jean was praised by Soso, another chauntuelle, who sang as follows:

(Pearse $1956: 254)$

Gros Jean, Gros Jean tu ni vue di tone

Gros Jean, Gros Jean tu ni vue di tone

Gros Jean, vue u leve mamma mwe mo.

(Gros Jean, Gros Jean, you have a voice like thunder Gros Jean, Gros Jean, you have a voice like thunder. Your voice can raise my mother from the dead.)

In 1838 , four years after slavery was officially abolished in the British Empire, ${ }^{4}$ the carnival became a celebration of freedom for the former slaves. Two major events introduced to the festival - canboulay, ${ }^{5}$ the re-enactment of the putting out of fires in the sugar cane fields during the period of slavery, and the stickfights or kalindas ${ }^{6}$ were to change the character ofthe

\footnotetext{
${ }^{4}$ Although the Act for the Abolition of Slavery in most of the colonies in the British Empire came into effect in 1834, slave labour was retained on the estates in Trinidad until 1838 under what was called an Apprenticeship Scheme which was supposed to prepare the slaves to assume the duties of free men and women but was seen by many as another form of slavery.
}

${ }^{5}$ The word is a corruption of the French ' cannes brueles ' which means burnt canes

${ }^{6}$ The kalindas (or kalendas ) are also a type of song and dance accompanying stickfighting. Led by the chauntuelles, the kalindas were the precursors of the calypso 
carnival which was almost taken over by people from the urban underclass or jamettes ${ }^{7}$ as they were called. The carnival itself then came to be known as the jamette carnival.

According to historian Bridget Brereton, the jamettes had created in the backyards ofPort of Spain, the capital of Trinidad,"their own subculture" and had formed "bands," groups of men and women and boys and girls - who were "especially active in the weeks before Carnival when they rehearsed their songs, dancing and stickfighting." (Brereton 1975, quoted in Warner 1983: 10) The chauntuelles who sang the battle songs at the stickflights, were the forerunners of the calypsonians.

One of the legendary female chauntuelles was Bodicea. According to Sampson, she had "a beautiful voice, a masculine face and was a wizard at extemporaneous verses "and her life was devoted to three things - "singing, drinking and fighting." (Pearse 1956: 261) She was remembered in song, though not in kindly fashion, for her impromptu performance in a cemetery where the disinterred and headless body of Hannibal, a noted stickfighter, was found at his graveside a week after his burial. According to Sampson, "when news of the incident went out,curious crowds flocked the cemetery "where Bodicea sang a calypso accusing a grave digger of stealing Hannibal's head.(Pearse 1956: 260)

\footnotetext{
${ }^{7}$ Derived from the French diametre ' diametre', the term jamette was used to refer to someone whose public behaviour was considered vulgar or obscene and thus outside the diameter of social responsibility. Today, the term is generally used to refer to a female prostitute.
} 
Sampson notes that "the calypso appealed to the crowd and they began to gyrate in the cemetery. Bodecia's shrill voice whipped them into unrestrained hilarity. The police came in and demanded the rouges to leave. The mirth-maddened carousers refused. Bodicea tore off her dress and waved it as a banner, still singing the captivating ditty. More policemen came in. They arrested Bodecia and five of her entourage."(Pearse 1956: 260-61)

Calypsonian Cedric Le Blanc, sang about the incident. The following is an excerpt from his song:

It was shocking, it was shameful and bad to see

Carnival in the cemetery.

It couldn't happen in Grenada

St. Kitts, Martinique or Antigua.

When such lawlessness can prevail

Tell me what's the use of the Royal gaol.

Bodecia, the jamette who we all know

Is a real disgrace to we Cariso...

The former slaves ushered in the carnival with canboulay, which Brereton describes as a "procession of band members, usually masked, carrying lighted torches and staves, which started at midnight on Carnival Sunday and continued until next morning. It was accompanied by a great deal of drumming, hooting, singing and shouting, and it was an occasion for fights between rival kalenda champions." (Brereton 1979: 170)The ruling class described the ceremony as "savage, indecent and illegal - only fit for the 'Negro Jardins " ${ }^{8}$ and by 1869 , they (the ruling class) and

\footnotetext{
${ }^{8}$ Field negroes or labourers
} 
the white community had "taken themselves completely out of Carnival..." ${ }^{9}$ (Elder 1966: 9697).

The colonial authorities made several attempts to restrict some of the canboulay activities. However, these attempts were met with strong resistance, leading to clashes between the police and carnival revellers and by 1881 when police attacked the masqueraders and tried to put out their torches, a full blown riot ensued. It lasted two days "during which the Military was called out and a force of soldiers from a visiting warship made to converge on the City of Port Of Spain." (Elder 1966: 101)

Elder writes about this historic incident as follows:

The whole city was in open rebellion and this was quelled only when the Governor organized a deputation of respected citizens to meet the people in the Eastern Market and address them. The troops having been made to withdraw, the Governor met the people and addressed them. This stopped the rioting ....Many civilians suffered and the damage among the police was considerable. Conflict over music and dancing had caused Trinidad its first major riot. (Elder 1966 :101)

Following the riot, the colonial government passed laws which further restricted canboulay activities. The torchlight processions were declared illegal, the playing of African musical instruments banned and "the old kalinda songs, deemed obscene and exciting to street-fights, went underground."(Elder 1966: 102-3).

\footnotetext{
${ }^{9}$ Later, members of the white community were to rejoin the annual celebrations and by the 20th century, there was greater participation by all groups. Liverpool writes that the various groups took part " at different levels and to varying degrees, and thus, slowly provided a base for the festival becoming a national one after 1962. ( Liverpool 2001: 486)
} 
Elder notes that in place of kalinda arose the " cariso " which was formerly sung by females during breaks in stickfight sessions. (Elder 1966: 109) This type of song was then "taken over by the male singers and adjusted rhythmically for street parades. Thus the cariso began another stage of its development towards social acceptance and status as the calypso ..."

( Elder 1966: 109)

In the period between the canboulay riot and 1920,"all the elements which have become important in the traditional calypso were developed," Elder notes. ( Elder 1966: 112). He summarizes the major developments as follows:

i. entry of white and middle class singers into cariso; introduction of English into the texts;

ii. incorporation of French Creole language into cariso texts;

iii. emphasis upon protest against injustice in the society and mis-rule in government.

iv. dominance of erotic themes and open reference to amorous encounters;

v. attempt of the 'new class' of singers to improve the calypso in literary style, introducing more complex musical forms while using the litany forms of the kalinda-songs as the basic melodic frame-work;

vi. improvement of the textual coherence of the songs;

vii. public cariso singing competititons organized (1899) (Elder 1966: 112)

It was in the post-emancipation period in the 19th century that many calypsonians started singing in English. About the transition in calypso from French to English, the calypsonian Lord Executor, (Philip Garcia) sang as follows:

From abolition to ninety-eight

Calypso was still sung in its crude state

From French to English it was then translated

By Norman Le Blanc ${ }^{10}$ who became celebrated

10 Norman Le Blanc was a white calypsonian known as Richard Coeur de Lion. 
Then it was rendered grammatically

In oration, poetry and history.

Warner notes that one of the earliest calypsos in English was "a reaction to a threat by the British to abolish the Port Of Spain City Council in 1898." However, he states that there is evidence that "calypsos - at least the forerunners of these songs- contained social commentary long before 1898." (Warner 1982: 67-68)

He cites historian Bryan Edwards who writes about the ability of the enslaved Africans in the West Indies "to give full scope to a talent for ridicule." According to Edwards who was himself a slave master, the slaves exercised that talent "not only against each other but also, not infrequently, at the expense of their owner or employer." He notes that "these owners or employers were obviously not prepared to tolerate this type of social protest from those who had no status in the society and whose songs were associated with a total lack of decency and respectability .The result was that by 1868 legislation was introduced prohibiting the singing of songs deemed profane." (Warner 1982: 68) Other legal challenges to freedom of expression in rhythm and rhyme were to follow. (See Chapter three.)

Different explanations for the origin of the term "calypso" have been put forward by various researchers .( Elder, Warner, Quevedo, Liverpool). According to one theory, calypso came from the Carib word 'carieto', which evolved in the 1850s into 'cariso' meaning a joyoussong. Another theory was that it was derived from the French patois term "carrousseaux" itself is derived from "carousse" meaning a drinking party or festivity. Yet another theory was that 19th century newspapers referred to calypso as "cariso," "caliso" and "calipso" so that "the word may well have been framed by the journalists." 
The Roaring Lion (Raphael de Leon) who declared in song that "Trinidad is the land of calypso," states, however, in his book, Calypso from France to Trinidad: 800 Years of History, that it originated in France. Describing it as a French folk song or "ballade," he claims that it was created by Guillaume de Machaut ${ }^{11}$ in 1295 (sic) and "later, the name 'calypso' was given to it..."( de Leon 1986:3)

Several researchers have quoted the explanation offered by the late Trinidadian singer Edric Connor regarding the origin of the word "kaiso" from which calypso was derived. Liverpool notes that Connor held the view that "kaiso" was a Hausa word which meant "bravo" or well done."(Liverpool 2001: 186) In The Trinidad Carnival: Mandate for a National Theatre, Hill concurs with Connor's view regarding the derivation of "calypso." He concedes, however, that evidence in support of this theory is not conclusive.(Hill $1997: 61$ )

Since the days of Gros Jean and Soso, calypso moved beyond the plantations and the streets at carnival time to the local calypso tents ${ }^{12}$ The development in Trinidad and Tobago of the steel pan (also known as the steel drum), one of the musical instrument invented in the 20th century, also had a major effect on popularizing calypso. The steel bands ${ }^{13}$ which play a great deal of the locally composed music, sprung up in various communities throughout the country. With the growth and development of the West Indian diaspora in North America and the United Kingdom, calypso has been heard at major concert halls in metropolitan centres such asCarnegie Hall in New York, Roy Thomson Hall in Toronto and the Royal Albert Hall in London, England.

\footnotetext{
${ }^{11}$ Guillaume de Machaut was a 14th century poet and music composer.

${ }^{12}$ A calypso tent is a venue, usually a hall or auditorium, where calypso concerts are held. The term "tent " is still used even though calypsonians in Trinidad and Tobago no longer perform in tents as they did up to the 1930 s.

${ }^{13}$ Steelbands are orchestras consisting of a variety of steel pans or steel drums.
} 
Since Trinidad and Tobago became independent in 1962, the government has promoted calypso as the country's national music and new musical styles have evolved. Among

the more popular ones are soca and chutney soca.

Calypsonian Ras Shorty (Garfield Blackman, also known as Lord Shorty) is credited with creating a blend of calypso and Indian music which he called sokah. It later came to be known as soca. Today, soca has not retained the Indian flavour in most of its compositions. However, with a faster beat than traditional calypso, it is the favourite music of calypso fans at parties and dances and is generally referred to as party music.

Like the original soca developed by Ras Shorty, chutney soca is also a blend of Indian and Afro-Trinidadian rhythms. This style of music is promoted by the Indo-Trinidadian community and the lyrics are often in Hindi , Bhojpuri and/or the English/Creole of Trinidad and Tobago.

With advances in technology, calypso in its various styles has become available on records ${ }^{14}$ and is broadcast on radio and television and via the internet. However, it is soca which propels the bands of masqueraders on the streets at the Trinidad carnival and the other annual Trinidad-style carnivals in places such as Toronto, New York and London, England. At these spectacular street parades, with "jump-up" music blaring from loudspeakers, it is unlikely that political commentary which are heard at the tents or concert halls or on the airwaves will be on the playlist.

\footnotetext{
${ }^{14}$ The year 2014 marked the one hundredth anniversary of the first vocal calypso recording in Trinidad. It was done by the Victor Talking Machine Company of the United States. The singer was Julian Whiterose who recorded under the sobriquet J. Resigna.
} 
In summary, this chapter provides an overview of the history of calypso. It traces its origins from the 18th century when enslaved Africans on the plantations in Trinidad kept their traditions in song and dance alive despite laws which made it illegal for them to do so. They were not permitted to play their musical instruments and assemble for music-making and dancing.

It notes the development of calypso after emancipation in the 19th century as the music of the carnival became a celebration of freedom for the former slaves. However, the carnival itself, which had been a festival exclusively for "the upper class of the community" and was taken over by people from the urban underclass, ran into problems with the colonial authorities who sought to restrict some of its activities and banned African musical instruments.

From the streets at carnival, the music later moved to the calypso tents and since Trinidad and Tobago became independent in 1962, has been promoted by the government as the country's national music. However, it continues to face major challenges.

The following chapter focuses on restraints to freedom of expression through the banning of the music of the enslaved Africans and censorship of calypso in the post-emancipation period. 


\section{Chapter Three}

\section{BANNING AND CENSORSHIP}

Where is the liberty of which they used to shout,

The freedom of speech they boasted about?

You're singing calypsoes and you are in dread

For I am asking openly and would like to know

What those Englishmen know about Calypso.

They really going too far I fear

What they can't do in England they doing here.

An excerpt from a 1936 calypso by Raymond Quevedo (Atilla the Hun) commenting on censorship in Trinidad and Tobago

Although African music and dancing were outlawed in Trinidad during the period of slavery which ended in 1834, the enslaved Africans, determined to keep alive their cultural traditions, defied the law. As Elder notes, "the blowing of the conch-shell, playing of the doun-doun ${ }^{15}$ and the deep Congo drums never really ceased," even though the slaves were punished for these infractions. (Elder $1966: 86$ ) Out of the struggle by the slaves to maintain their musical traditions, calypso evolved. But in the post-emancipation period, with the imposition of censorship and other restraints, ${ }^{16}$ came a further struggle - the fight to keep calypso alive.

In Trinidad "as early as May 30, 1797, Police regulations demanded that enslaved

${ }^{15}$ An hour-glass-shaped, skin-covered, wooden drum, with very deep tone

${ }^{16}$ Official censorship of calypso under the Theatres and Dance Halls Ordinance ended in 1951.But calypsonians were later subjected to what this thesis describes as unofficial censorship from the local radio and television stations and calypso tents. Some of the singers who were identified with a particular political party also practice self-censorship. ( See Chapter six) 
Africans needed permits ' to dance till the firing of the Evening gun ' - 8.00 p.m. Dancing was otherwise prohibited, except, of course, with the permission and under the control of Whites...An order of 1801 again prohibited ' Negro dances in town.'" ( Liverpool 2001 : 159)

Even before the slaves were freed, laws were in effect to control the activities of the Africans at the carnival. Liverpool notes that the fact that Port of Spain, the capital of Trinidad, was "the centre of carnival activity caused the government to institute Ordinance No. 4 of 1835 establishing an effective system of Police within the town.' Masking was prohibited as well as the beating and playing of 'any drum, gong. tambour (French for drum), banjee ${ }^{17}$ or chac-chac ${ }^{18}$ in any house, outhouse, building or yard before 5.00 a.m. and after 8.00 p.m." (Liverpool 2001: 160)

Liverpool argues that the ban placed on these instruments "was effectively a ban on the earliest forms of calypso since these instruments would be used in playing the Kalenda, the stickfight dance and song." He notes that the "Kalenda chants which funnelled into the calypso, contributed to the defiant nature which Calypso and calypsonians exhibited in the 19th and 20th centuries ." (Liverpool $2001: 164)$

After emancipation, calypso had moved from the plantations to the streets at the annual carnival and to the calypso tents where in 1930 police began keeping a close watch on performances. That year Raymond Quevedo, a calypsonian known as Atilla the Hun, criticised a magistrate in song for arraigning a solicitor for contempt of court. In his book, Atilla's kaiso: a

${ }^{17}$ A stringed musical instrument with a small round resonant box

${ }^{18}$ A rattle-type musical percussion rhythm instrument 
short history of Trinidad calypso, Quevedo writes that this calypso was inspired by an incident which had occurred in the police court. He notes that "during the proceedings a solicitor sucked his teeth in apparent disgust and the bench, taking umbrage, arraigned him for contempt...The incident created a furore in local and West Indian circles." (Quevedo 1983: 56) He sang as follows:

\author{
Kenneth Vincent Brown \\ You always doing something that's wrong \\ Kenneth Vincent Brown \\ You always doing something that's wrong \\ West Indian papers all freely state \\ That you are no good as a magistrate \\ For you always cause dissatisfaction \\ With your rotten jurisdication.
}

Kenneth Vincent Brown, a Trinidadian born

Whose line of ancestry no one can scorn

City magistrate for eight years or more

His mode of dispensing justice we all deplore

Ah what would this island be

If every other official was like he

It would be the dawn of slavery

And the death of liberty

In this colony.

It was after Quevedo sang that calypso that the police ordered "all tent performances " to end at 10 p.m. "thereby enforcing a 19th century ordinance which forbade the unlicensed playing of any loud musical instrument between 10 p.m. and 6.00 p.m." - a measure which Quevedo viewed as "deliberate harassment." (Liverpool 2001: 278)

Quevedo notes that about this time, the head of the police force instituted the custom of calling calypsonians into his presence, "ostensibly to give them benignant advice but actually to subtly terrify them." The police chief suggested "they should be careful about what they sang on [about] what he called respectable people. Though not openly threatening, he covertly implied 
that serious consequences might follow if his advice were not heeded." (Quevedo 1983: 57) But despite police warnings, many of the bards continued to target the elites in song, attracting considerable - though clearly unwanted - attention from the colonial authorities.

One such song by King Radio (Norman Span) dealt with a scandal in which one of the highest-ranking police officers in the island was said to have been "caught in bed with the wife of a distinguished official." (Liverpool 2001 : 431) Quevedo writes about the drama which unfolded in the tent where King Radio was to sing his calypso.

Never before were so many uniformed policemen present in a tent at one time.A policeman brought a message on stage to say that the kaiso in question must not be sung. Kaiso singers promptly appealed to Captain A.A. Cipriani who was a member of the Legislative Council and the Executive Council, and leader of by far the biggest political party in the country. He replied in a stentorian voice, which rang through the tent:

"Put a chair for me on the stage and sing your song. Let the police do their damnedest. I am by your side."

The kaiso singer, not yet fully reassured, continued: "Captain, the police threatening to lock me up,"

Captain Cipriani immediately went on stage replying: "I am with you. Go ahead and sing your song." ( Quevedo 1983:57)

The following is an excerpt from the calypso which was then sung:

From the swimming pool

To the servant's room

That is where

Mrs. X met her doom.

The Country Club scandal

Was a hideous bacchanal.

According to Quevedo, no arrest was made at the tent. But he notes that calypsonians all felt that "this incident brought the wrath of the gods on their heads and that the issue was not closed. But even the most discerning could not foresee the extent and form the reprisal would take. So it came as a bolt from the blue when in 1934 the government passed as law the Theatres 
and Dance Halls Ordinance as a further oppressively restrictive measure." (Quevedo 1983 :57)

About the new legislation, Quevedo writes as follows:

The Ordinance set up the benighted police and more particularly alien high-ranking officers as the supreme authority over the kaiso, a most anachronistic situation in 1934, bearing in mind the difficulty if not impossibility of an itinerant Englishman understanding the subtleties, innuendos, insinuations and nuances connected with this art medium. The kaiso singer was now at the mercy of the police. The police were both judge and jury and there was no appeal against their decision. In addition to this, the Colonial Secretary, another bird of passage, reserved the right to ban kaiso records. Kaisonians could not sing in tents without a licence duly signed by the police officer superintending the district. And when it was considered that there was always the implied threat of withholding his license if certain songs that didn't have the fullest approval of the police were persisted with, it is clear that the kaisonian was singing with a veritable sword of Damocles hanging over his head, a condition which cannot be conducive to the fullest expression in any form of art. (Quevedo 1983: 57-58)

As Gordon Rohlehr, a former professor of West Indian literature at the University of the West Indies, notes in Calypso \& Society in Pre-Independence Trinidad, a significant partof a programme of legislation aimed at "policing the thought of the colony" was the Theatres and Dance Halls Ordinance of 1934. (Rohlehr 1990: 288) This, he said, was to become "the major bugbear of calypsonians." (Rohlehr 1990: 293)

Rohlehr also notes that one of the regulations of the ordinance placed both the calypsonian and the manager of the calypso tent under the control of the Inspector General of the constabulary who decided whether a song was profane, indecent or obscene or whether it was insulting to any individual or group. However, the ordinance did not put a stop to the composition of political calypsos. In fact, according to Rohlehr, these calypsos "continued to 
flourish throughout the period." He notes that "the presence of policemen in the tents may have helped control some singers though the fact that improvisation remained a skill among older singers meant that calypsonians sometimes counter-attacked their tormentors by singing impromptu ...against the policemen present in the tent." ( Rohlehr 1990: 294)

He writes that the calypsonians "resented and resisted even the legitimate authority of the Police, often refusing to submit the texts of calypsos for scrutiny before singing them in the tents and policemen assigned to tents were at times forced to copy down the words of questionable calypsos." (Rohlehr 1990: 295) Of the police presence in the calypso tent, Quevedo sang as follows:

There are police spies sitting around

Taking shorthand notes of my song

But I can tell them independently

That they can tell their masters for me

Never mind whatever measures are employed

Kaiso is an art and cannot be destroyed

And centuries to come I'd have them know

People will still be singing kaiso.

Quevedo's prophecy that people will be singing kaiso "centuries to come" is yet to be fulfilled. However, during the period of censorship under the Theatres and Dance Halls Ordinance (1934-51) when he presented his "editorials in song," he and many of his fellow calypsonians demonstrated a dogged determination to let their voices be heard on the issue of interest to large sections of the population. These issues might not have reached the attention of many, had it not have been for calypso or the poor man's newspaper, as it was then called.

Calypso records did not escape the scrutiny of the censors and many popular songs were banned. An entire shipment of the first issue of Netty Netty, a song by The Roaring Lion about 
a prostitute, which was banned by the Commissioner of Police in 1936, was dumped in Port Of Spain harbour.

The banning of records was itself the subject of a calypso by Quevedo. The following is an excerpt from that song:

For the benefit of those who didn't know

Calypso is our heritage from long ago

But many of the puritans in this land

Against the singers took a stand (I) can't understand

They hate to have their linen washed in public

So they devised this scurvy trick

To apply pressure strong and viberous

And attempt to take our music from us

' Honi soit qui mal y pense' is my cry

'Evil to him who thinketh evil, ' say I!

It's well known a man with a perverted mind

With the most moral work some fault he will find.

If 'Netty Netty' is indecent, then I insist

That so is Shakespeare's 'Venus and Adonis'

But o'er these writers they make no fuss

But poor we, they want to take our culture from us.

Quevedo who became a member of the Port of Spain City Council and later a member of the country 's Legislative Council, was relentless in his attack on censorship. His calypso on the The Banning of Records was itself banned but he took his fight against censorship to the Legislative Council in 1951 where he spoke out against the repressive legislation when recommendations of a committee on the functioning of the Theatres and Dance Halls Ordinance were debated. The Council accepted recommendations that the licensing authority for theatres and dance halls be taken away from the police and placed in the hands of a magistrate and that calypsonians be allowed the right to appeal, if their licence to perform were denied or withdrawn.

Censorship (under the Theatres and Dance Halls Ordinance) continued until 1951 when the law was amended, closing an important chapter in the history of the struggle of the 
calypsonians to keep alive the art form, a period which can be described as the golden age of calypso.

Alluding to the golden age of calypso, Raphael de Leon (The Roaring Lion) places that period in the history of the art form "during the 1920s up to the 1940s" (de Leon 1968: 88) while Quevedo writes that calypso was "bursting into flower" in the 1940s.(Quevedo 1983: 79) However, some aficionados of the music believe that the golden age of calypso began later - in the 1950s - when American singer Harry Belafonte helped to popularize the music internationally through his records. ${ }^{19}$

Let us first consider the period identified by de Leon. In Calypso from France to Trinidad: 800 Years of History, he notes that "the calypsos composed during the 1920s up to the 1940s, were of a very high standard and quite a few must go on record as classics. They will do justice to any library or university; and in Trinidad literature they are high on the list." According to de Leon, during this period, the calypsonians were "made every effort to produce compositions of a high order. They were aware that the calypso is poetry, and as such, it had to measure up to standards. It was this acknowledgement that resulted in what deserves to be termed the ' Golden Age of the Calypso."' ( De Leon 1968: 88)

Quevedo writes that as far back as the early 1900s," a group of young intellectuals had spearheaded a drive to infuse calypso with 'a spirit of change'" and that plans were made to improve the lyrics "and a great coherence of expression was aimed at." The final objective, he explains, was "to break with the past, with the crude primitive modes of presentation." (Quevedo1983:79) He notes that "after the first flush of success, 1900-1905, the new movement

${ }^{19}$ Harry Belafonte's Calypso and Elvis Presley's Elvis Presley are two albums which are reported to have been the first to sell one million copies. Both were released in 1956. 
slumped, and the old norms again took over" But in the 1940s, "further impregnated with change, and yet more change," calypso was "bursting into flower." (Quevedo 1983: 79)

By the 1950s, after official censorship of calypsos in Trinidad and Tobago had ended, there was a further blossoming of the art form. American singer Harry Belafonte who is not a calypsonian, had recorded many calypsos. The songs received a great deal of airplay which popularize the music internationally. Some calypso aficionados consider the period of the $1950 \mathrm{~s}$ when the calypsos which were sung by Belafonte were at the top of the charts, as the golden age of calypso.

However, this thesis argues if there were a golden age of calypso, it had to be the period when the creative talents of the composers blossomed in spite of the harsh colonial environment of censorship. It therefore had to be that time when artistes outwitted and defied the authorities in order to deliver their messages - their "editorials in song" - in the calypso tents. That was the period when calypso might have been correctly described as "the poor man's newspaper" - the period that corresponds to the time when the censorship laws were in effect under the Theatres and Dance Halls Ordinance - 1934 -51. Identified with this challenging era were calypso stalwarts such as Atilla the Hun, Growler, Roaring Lion, Tiger, Pretender and King Radio.

In summary, this chapter focuses on the legal restraints imposed on calypso from its origins on the slave plantations in Trinidad to the post-emancipation period when censorship under the Theatres and Dance Halls Ordinance came into effect.(1934-1951) However, greater attention is devoted to the post-emancipation period when calypso tents were established.

Calypsonians and managers of the tents were both placed under the control of the Inspector General of the constabulary who decided whether a song was profane, indecent or 
obscene or whether it was insulting to any individual or group. Calypsonians who were then required to submit to the police the texts of their songs for scrutiny before singing them in the tents, often refused to do so. (Rohlehr 1990: 294-95)

One of the calypso stalwarts of the period, Raymond Quevedo (Atilla the Hun) took the fight against censorship to the country's Legislative Council of which he was a member. He spoke out against the repressive legislation when recommendations of a committee on the functioning of the Theatres and Dance Halls Ordinance was debated. The Council accepted recommendations that the licensing authority for theatres and dance halls be taken away from the police and placed in the hands of a magistrate and that calypsonians be allowed the right to appeal, if their license to perform were denied or withdrawn.(Quevedo 1983: 63)Censorship under the Theatres and Dance Halls Ordinance continued until 1951 when the lawwas amended.

According to Gordon Rohlehr, censorship in the colonial period did not put a stop to the composition of political calypsos. In his book Calypso \& Society in Pre-independence Trinidad, Rohlehr writes that that they "continued to flourish throughout the period." (Rohlehr 1990: 294). This chapter argues that if there were a golden age of calypso it had to be the period when the creative talents of the composers blossomed in spite of censorship.

The following chapter examines the development of political commentary in calypso in Trinidad and Tobago from 1956, several years after censorship under the Theatres and Dance Halls Ordinance ended, to independence in 1962 and several years beyond. 


\section{Chapter Four}

\section{FROM COLONIALISM TO INDEPENDENCE AND BEYOND}

For many years during the colonial period in Trinidad and Tobago, as calypsonians railed against censorship, there was clearly an uneasy relationship between the singers and the government. However, by 1956, there was a noticeable change. That year calypsonians were jubilant when a new political party, the People's National Movement (PNM), came to power in the two-island state. The PNM was led by Dr. Eric Williams, an Afro-Trinidadian academic who was educated at Oxford University in England and was seen by many in Trinidad and Tobago as a messiah whose political party would lead the country to independence - which it did in 1962.

However, Dr. Williams, was no messiah, as his supporters came to realize, even though as calypso researcher Louis Regis notes in his book, The Political Calypso: True Opposition in Trinidad and Tobago 1962- 87, he (Dr. Williams) "became the darling of the calypsonians largely because he was their living legend who had destroyed myths of black intellectual inferiority by his own effort and achievement " and "had presented himself as being totally committed to destroying the colonial system and securing his people's welfare." ( Regis 1999: 1)

One of the best known of the early calypsos in praise of Dr. Williams was William the Conqueror which was sung by the Mighty Sparrow who has been described as the "calypso king of the world." The following is an excerpt from that calypso:

I am no politician

But I could understand

If it wasn't for Willie

And his ability

Trinidad wouldn't go, neither would come. 
We used to vote for roti and $\mathrm{rum}^{20}$

But nowadays we eating all the Indians and them

And in the ending, we voting PNM.

\section{Chorus}

Praise little Eric, rejoice and be glad

We have a better future here in Trinidad.

P.N.M. It ain't got nobody like them

For they have a champion leader

William, the Conqueror.

Quoting the Trinidad Guardian, one of the daily newspapers published in Trinidad and Tobago, Regis notes that by 1957 "there was not an anti-government calypso in sight." (Regis 1999: 4) However, for Dr. Williams and his government, the freedom from criticisms in the "editorials in song" soon ended, even though some calypsonians continued to support the PNM.

For many years, the Mighty Sparrow was well known as a supporter of Dr. Williams and the PNM government. One of his calypsos which Regis describes as "a masterpiece of pro-PNM propaganda" dealt with the introduction of a new income tax system in Trinidad and Tobago (Regis 1999:8). It was called the Pay As You Earn or PAYE system. The calypso won the Road March ${ }^{21}$ at the 1958 Trinidad carnival and was described by Dr. Williams in his autobiography, Inward Hunger, as "one of the best calypsos in Trinidad's history" (Williams 1971: 248) - hardly an impartial assessment of the song, coming as it did from the head of the government which introduced the tax. The following are the lyrics of that calypso:

\footnotetext{
${ }^{20}$ According to the Dictionary of the English/Creole of Trinidad and Tobago, roti and rum is a style of political campaigning in which voters are given food and drink to encourage them to vote for a particular party.

${ }^{21}$ The Road March is not in fact a march. The term is used to refer to the calypso that is most often played at judging points on the streets of Port Of Spain at the annual Trinidad carnival.
} 
It's a shame, it's a shame

But we have weself to blame (repeat)

Because we ask for new government

Now they taking every cent

Cost of living is the same

So it's really a burning shame.

Chorus

The Doctor say to pay as your earn

But Sparrow say you paying to learn

And meh father say he sharpening the axe

So when the collector come to pay off the income tax.

First of all we want better schools

So we children won't grow up as fools

Then work for you and me

That is what plenty and them cyar see

Everybody is in misery

But this tax ent bothering me

For I ent working no where

And I have no income to share

But Mr.This and Mr.That

Who accustom with they payroll fat

Is to see them shedding tears

Men like De Freitas and Fernandez.

When the Doctor went up to England

They bluntly refused to support his plan

So there is nothing more he could do

Then to get it from me and you

That the law now in Trinidad

If you don't like it that's too bad

Take your things and clear out today

For all who working must pay.

By 1961, the West Indies Federation ${ }^{22}$ was in crisis as Jamaica decided to secede. Regis notes that during that period, the Mighty Sparrow 's support for Dr. Williams was "total and unquestioning." (Regis 1991 : 9 )His calypso blaming Jamaica for the break-up of the

${ }^{22}$ Trinidad and Tobago was one of ten British colonies which comprised the short-lived West Indies Federation which was established in 1958. The Federation broke up in 1962. 
federation was well received in Trinidad and was one of his songs which brought him victory that year at the annual calypso king competition. The following are excerpts from that calypso:

People want to know why Jamaica run

From the Federation.

Yes, they want to know why Jamaica run away

From the Federation.

Jamaica have a right to speak she mind

That is my opinion

And if you believe in democracy

You'll agree with me.

\section{Chorus}

But if they know they didn't want Federation

And they know they didn't want to unite as one

Independence was at the door

Why didn't they speak before

This is no time to say you ain't Federating no more.

With the attainment of political independence in Trinidad and Tobago, the PNM

government proceeded to "nationalize" carnival and calypso competitions. In an independence

calypso king competition in 1962, the Mighty Sparrow did not win the crown but his song in

praise of the two-island state, titled Model Nation, was well received. It is perhaps the best

remembered calypso in the contest. He sang as follows:

The whole population of this little nation

Is not a lot

But oh! what a mixture of races and culture

That's what we've got

Still no major indifference

Of race, colour, religion or finance

It's amazing to you I'm sure

We didn't get independence before.

\section{Chorus}

Trinidad and Tobago will always live on

Colonialism gone our Nation is born...everybody 
We go follow our leaders

They always do their best, oh yes

We want to achieve, we going to aspire

We bound to be a success.

You people who are foreign

Ah got a message to give you when you going

Spread the word everywhere you pass

Tell the world there is a model nation at last

The revenue we make from oil and the Pitch Lake

Is great but wait

We got cocoa and copra, bananas and sugar

Coconuts, citrus

We are small but we wealthy

Pound for pound we beat New York City

We got beaches and hotel built by Hilton

Our Nation ent second to anyone.

You may not believe this but we didn't achieve this

With floods of blood

It is leaders like Butler, Cipriani and the Doctor

They fight for what is right

So now I am congratulating

All our leaders from the present back to the beginning

They have fought now the battle is won

Thanks for a good job well done.

The winner of the competition was Lord Brynner (Kade Simon) whose song, This land

is mine, is seldom heard on the airwaves. It is perhaps best remembered by some calypso

aficionados for a few lines in which he dealt in a nonsensical fashion with the sensitive and

complex issue of race. Lord Brynner sang as follows:

Conscientiously and constitutionally

Forget all this lousy rumour 'bout racial equality.

If you are an East Indian

And you want to be an African,

Just shave your head clean like me

And then they can't prove your nationality.

Lord Brynner's suggestion to people of Indian descent to shave their heads might have

stirred up racial animosity in another context but taken in good humour in the euphoria of 
independence, it provoked no such reaction. The song itself seemed to have been quickly forgotten.

Among the calypsos in praise of Trinidad and Tobago, none presented at the 1962 Independence competition matched Portrait of Trinidad, which was first sung in 1965 by the Mighty Sniper (Mervyn Hodge). It is often described as the "unofficial national anthem of Trinidad and Tobago."

The staid national anthem of the two-island state sounds like a Victorian hymn and lacks the verve and spirit of what is proudly described as the "national music" of Trinidad and Tobago. But Portrait of Trinidad, rendered in the Creole English of the local bards, resonates in the familiar rhythms of the streets of Port of Spain. The following is an excerpt from the calypso:

Trinidad is my land

And of it I am proud and glad

But Ah cyar understand

Why some people does talk it bad.

All ah dem whey running dey mout

Doh know wha' dey talking 'bout.

They will paint here black every day

And the right things they will never say.

\section{Chorus}

Like our sportsmen being rated among the best

Our scholars have sat and passed every test

And they rank along the best

And then our Pitch Lake is the greatest one of its kind

Our sugar and oil is really refined.

So you see, friends, this is a real King Solomon's Mines

They does talk some nonesense

Meh ent know what they doing it for

'Bout so much violence

Man, you would swear that we fighting war.

We have we delinquents to face

But just like any other place 
Look the things they does say 'bout here

Is really too much for me to bear.

\section{Chorus}

Because my people are daily making progress

Without any form of stupidness

And in this way we must gain success

For when we moving, we all move as one body

No bickering between you and me

And our policy stands for racial equality.

Like many of the calypsos which promote national pride and are described as nationbuilding songs, Portrait of Trinidad is not without some measure of hyperbole. It is to be noted, however, that hyperbole is one of the well used tools of the local bards with which they embellish their lyrics.

During the 1960s, while some artistes continued to sing the praises of the PNM, dissenting voices were heard on the calypso stage. As Regis puts it, "new and different focus was given to the problems of unemployment and youth violence which were now being seen as manifestation of the failure of the PNM to deal with the distribution of wealth in the society." (Regis 1991: 44)

Even the Mighty Sparrow, the long-time champion of Eric Williams and the PNM, changed his tune with some critical lyrical messages. His song titled Honesty is a good example of that change. ${ }^{23}$ The following is an excerpt from Honesty:

${ }^{23}$ Although the Mighty Sparrow sang calypsos in which he criticized politicians and complained about problems such as rising food prices, he claims in an interview that he did not switch his political allegiance as was reported in the media in Trinidad and Tobago. According to media reports, he had shifted his support from the PNM (People's National Movement ) to the now defunct Organization for National Reconstruction. (Interview with the Mighty Sparrow November 24, 2014) 
It's good to be honest, I wouldn't deny

But through dishonesty plenty people get by.

To cheat and to lie is very very wrong

But that's the way politicians get along.

The amount of lies politicians tell

When they dead all of them going to hell

In 1970, Trinidad was rocked by an uprising which came to be called the Black Power revolution. ${ }^{24}$ Students, political activists, trade unionists, academics, a cross section of the unemployed and others took to the streets in a series of demonstrations to protest social problems in the country and show solidarity with arrested Caribbean students at Sir George Williams (now Concordia) University in Montreal. The students who complained about racial discrimination at the university, were arrested along with others, after an illegal sit-in and riot on campus.

The National Joint Action Committee (NJAC), the umbrella group which led the protest demonstrations in Trinidad, was formed on the St. Augustine campus of the University of the West Indies (UWI) in response to the arrests of the Caribbean students in Montreal. According to Aiyegoro Ome, the NJAC chairman, a request came to the UWI Student Guild in Trinidad to assist in raising the issue of the "imprisoned Caribbean students" from Sir George Williams University. ${ }^{25}$

"Mobilization began on the campus of the university towards this end" and provision was made for the formation of the umbrella group, Ome noted. ${ }^{26}$ The NJAC chairman recalled that "mobilization intensified" when Canada's Governor General Roland Michener visited the Caribbean and was due to pay a visit to the St. Augustine campus of the university. On February

\footnotetext{
${ }^{24}$ The so-called Black Power revolution in Trinidad was influenced by the civil rights movement in the United States. The late Stokley Carmichael, a Trinidad-born US civil rights activist is credited with originating the "black power" slogan in the 1960s.

${ }^{25}$ Personal correspondence with Aiyegoro Ome, chairman of the National Joint Action Committee of Trinidad - May 25, 2015

${ }^{26}$ Ibid
} 
26, 1969, Michener was blocked from entering the campus by a group of UWI students who later held the first meeting of the umbrella group, the NJAC chairman said. ${ }^{27}$

To quell the disturbances in Trinidad, the government of Prime Minister Dr. Eric Williams declared a State of Emergency and the leaders of the insurrection were rounded up and imprisoned. In response to this, a section of the Trinidad and Tobago Regiment ${ }^{28}$ took up arms against the government and demanded the release of the civilian detainees. However, Trinidad and Tobago's well-armed Coast Guard, which remained loyal to the government, put down the mutiny. After a stand-off lasting several days, the leaders of the mutiny surrendered and were arrested and charged with mutiny and treason.

Clearly, the government of Trinidad and Tobago, led by Dr. Williams, had not brought about the social change which it had promised. While calypsonians who sang about the insurrection did not call for the overthrow of the Williams regime, some supported the demonstrations. One of them, Brother Valentino (Anthony Emrold Phillip), in his composition titled No Revolution, complained about the action taken by the authorities against the demonstrators. The following is an excerpt from his calypso:

They talking 'bout power, Doctor, is you who have power Ah know when you act woulda be a horse of a different colour. You give them a inch, they take a whole yard

And when you had them under your clinch people say you bad

Well when I heard you address the Nation

I know what was your intention

But some of the powers you exercise

Unfortunately I must criticize.

\footnotetext{
${ }^{27}$ Ibid

28 The Trinidad and Tobago Regiment (the country's army) is a major part of the Trinidad and Tobago Defence Force (TTDF) which also includes the county's Coast Guard, Air Guard and Defence Force Reserves.
} 
We didn't want them trigger-happy police

We only wanted to demonstrate in peace

Yet you held my people and charge them for sedition

We was marching for equality

Black unity and Black dignity

Dr. Williams, no, we didn't want no revolution.

Another leading political commentator in song, Chalkdust (Hollis Liverpool), also

weighed in with his calypso titled Answer to Black Power. The following is an excerpt:

You giving the unemployed every year

Jobs to mend the streets here and there

But that wouldn't solve the situation

You only sowing the seeds of revolution.

You got to create more opportunity for all black men in society

With the emphasis

On helping them to form their own business.

Doctor the answer to solve Black Power

Is to tax the rich some more

And build houses for the blind, the lame and the poor.

Houses for everyone we must ensure

Vital areas like sugar and oil

Must be run by sons of the soil.

Why must the small white minority

Control us economically?

Make sure that our black majority

Fill up every hole, nook and cranny

That's the answer for Black Power.

In Chalkdust's Answer to Black Power, his proposed solutions to the social problems in the country may have found resonance with the local protesters caught up in the rhetoric of the black power movement. However, his suggestions clearly did not take into account the multiracial composition of the society. For the government of Trinidad and Tobago to have privileged a particular group - people of African descent - when it was supposed to be governing on behalf of everyone in the society would undoubtedly have led to alienation of the large group of people of Indian descent as well as other groups, creating further conflicts. 
By 1986, "the wheel had come full circle for the PNM," according to Regis. He notes that "in 1956 they had blamed the country's troubles on colonialism. 'Colonialism,' Williams had declared dramatically, 'There's the enemy."' But by 1986, "PNM had completed the Orwellian transformation to become that enemy." (Regis 1999: 179) That year the PNM was defeated in general elections, ending its unbroken 30-year rule.

Two outstanding calypsos - The Sinking Ship and Vote Dem Out - became popular campaign songs for the National Alliance for Reconstruction (NAR), a coalition of political parties which won the 1986 general elections. The Sinking Ship was credited by its composer - Gypsy (Winston Peters) - with bringing down the PNM government. (See chapters six and ten) Regis notes that "perhaps the most intriguing feature about 'The Sinking Ship' was that it provided a symbol which many could appropriate, each for his own purpose." (Regis 1999: 178)

The following is an excerpt from The Sinking Ship:

The 'Trinidad', a luxury liner

Sailing the Caribbean Sea

With an old captain named Eric Williams

For years sailed smooth and free

But sadly Eric Williams passed away

The ship hit rough water that day

Somebody turn the bridge over

To a captain named Chambers

Mid blood crawl

Thing start to fall

Hold mih head when a sailor bawl

Captain, the ship is sinking!

Captain, the seas are rough

We gas tank almost empty

No electricity

We oil pressure reading low

Shall we abandon ship

Or shall we stay on it 
And perish slow

We don't know, we don't know

Captain, you tell me what to do

(ii) The 'Trinidad', oh she was a beauty

With wealth that few surpassed

And in her days she sailed majestically

There were few in her class

Faithfully she fulfilled her sailors' need

Some were overpowered by greed

And so they pilfered slow

Some took by bulk and go

Now she looks dull, she's at a lull

She can barely sit on her hull

Like The Sinking Ship, Vote Dem Out, composed and sung by Deple (Tyrone

Hernandez) was popular on the campaign trail. As Regis observes, Deple's calypso "met all

the specifications of a campaign song; its aggressive kalinda antiphony could be sung, chanted

and danced; it convinced the voter of the power of his vote and did not make any electoral

promises." (Regis 1999: 180) The following is an excerpt from Vote Dem Out:

Your vote will decide

Our destiny

Your vote will decide

What you want to be

Your vote can foretell

Our country's fate

Go and use it well

Before it is too late.

If it is that you who vote may be on a doubt

When you voting, vote them out, vote them out

If it is that they proving to be only full of mout

When you voting, vote them out.

If it is the time is now that this should come about

When you voting, vote them out.

Register and

Vote them out

If they duncie 


\section{Vote them out}

Stain your finger and

Vote them out.

Show them no mercy

Vote them out

The new NAR government, headed by Prime Minister A.N.R. Robinson, which swept to power, winning 33 of the 36 seats in Parliament, soon found itself in disfavour with large section of the population. About this situation, Regis writes as follows:

His first budget of sacrifices was but the first in a series of austerity measures which angered the masses, his rigid authoritarianism annoyed his confederates, his expulsion of $\mathrm{ULF}^{29}$ populists alienated the Indo-Trinidadian voters and his obsession with demolishing the Williams ${ }^{30}$ godhead antagonised the Afro-Trinidadian voters. Different groups cultivated private grievances, some manufactured, others magnified, and the aggregate fury of the real and the perceived fell with triple vengeance on the once putative saviour. Calypsonians featured prominently in the anti-Robinson blitz.( Regis 1999: 238)

In 1990, in an attempted coup, the Jamaat al Muslimeen, a radical Islamic group, stormed the Trinidad and Tobago Parliament and held hostage Prime Minister Robinson, several of his cabinet ministers and others. Before the insurgents surrendered several days later, 24 people were as a result of the insurrection and Prime Minister Robinson and Selwyn Richardson, the Minister of National Security, were shot in their legs after being beaten. Yasin Abu Bakr, the leader of the Jamaat al Muslimeen and 113 of his followers were arrested and charged with treason, murder, kidnapping and other offences but they were freed after a high court judge in Trinidad ruled that a presidential pardon, which they had received was valid. ${ }^{31}$

${ }^{29}$ The United Labour Front (ULF) headed by Basdeo Panday, an Indo-Trinidadian lawyer, was one of the political parties within the coalition NAR government.

${ }^{30}$ Dr. Eric Williams who led the People's National Movement (PNM) for several decades, died in 1980.Prime Minister Robinson was himself a member of the PNM government.

${ }^{31}$ Dean, Darryl "Are rebels still a threat in Trinidad?" Toronto Star, May 8, 1992 P.A15 
In terms of political commentary, the attempted coup was not the calypsonians' finest hour. As Regis notes, "calypsonians delighted in ridiculing Robinson who had borne himself with dignity and courage despite the humiliations imposed on him by the insurgents. Very few singers thought to reflect deeply on the Muslimeen's exercise in tragicomedy." (Regis 1999: 238)

By 1991, the unpopular Robinson government was defeated in general elections and the PNM returned to power under the leadership of Prime Minister Patrick Manning, one of the three members of parliament who were on the opposition benches during the one-term NAR regime. But by 1995, the PNM was again out of office and Basdeo Panday became the first IndoTrinidadian prime minister and the target of many calypsos. In response, Panday had threatened to cut off state funds for calypso which was seen as promoting racism and division in the society. (See chapters five and six) Since the 1990s, there have been several changes in government and the current head of government is Kamla Persad-Bissessar, another Indo-Trinidadian and the country's first woman prime minister.

In summary, this chapter notes the change in relationship between calypsonian and government after the period of official censorship and traces the development of calypso from 1956, to political independence in Trinidad and Tobago in 1962 and beyond.

In 2015, while there is no official censorship of calypso, self-censorship is a growing concern as some calypsonians, radio and television stations and calypso tents muzzle themselves for political and economic reasons. (See Chapter six) From official censorship in the colonial period to unofficial censorship and self-censorship at the present time, calypso continues to face 
major challenges and political commentary in rhythm and rhyme has become an endangered species. The following chapter examines identity, race and gender in Trinidad and Tobago's multicultural society in relation to the art form. 


\section{Chapter Five}

\section{IDENTITY, RACE AND GENDER}

In multicultural Trinidad and Tobago where the national anthem declares that "every creed and race find an equal place," identity remains a contested issue and calypso is sometimes seen as divisive . Some compositions promote negative stereotypes about groups such as IndoTrinidadians and women. Such stereotypes can be traced back to the country's colonial past.

Although Trinidad and Tobago is home to people from several racial groups, those of African and Indian descent - the two larger groups - each make up about 40 per cent of the country's total population of about 1.3 million. There are also growing numbers of people of mixed African and Indian descent, or douglas as they are called.

The perception, widely-held by people of African descent, that Indians were brought to Trinidad to undercut the wages than they (the Afro-Trinidadians) had expected in the postslavery era, ${ }^{32}$ has had a negative impact on race relations between the two groups in what has become a contested cultural environment. It is one in which racial and gender stereotypes have been prominent in calypso, as Shalini Puri points out in her book, Postcolonial: Social Equality, Post-Nationalism and Cultural Hybridity,

${ }^{32}$ After the emancipation of the African slaves in Trinidad in 1838, as labourers from other West Indian islands, the United States and West Africa entered the labour market in the country, wages on the sugar estates in the island were reduced. This happened before 1845 when indentured labourers from India started arriving in Trinidad to work on the estates. Dennison Moore, author of Origins \& Development of Racial Ideology in Trinidad, says despite claims to the contrary, the arrival of the Indian workers had little or no impact on the level of wages paid to the estate workers. 
Puri and several other writers, among them Gordon Rohlehr and Zeno Obiageli

Constance allude to the stereotypes with respect to people of Indian and African descent. For example, "the thriftless African/ the thrifty Indian; the lazy African/the hard-working Indian; the child-like African unable to control his sexual appetites/ the calculating and ascetic Indian." (Puri 2004: 173)

Tracing racial stereotypes back to the colonial period, Puri notes the remarks of the 19th-century British historian James Anthony Froude about people of African and Indian descent in Trinidad. She quotes him as saying that "the negro does not regard the coolie ${ }^{33}$ as a competitor and interloper who has come to lower his wages. The coolies come to work. The negro does not want to work, and both are satisfied."(Puri 2004: 172) She also quotes the

Trinidadian writer and Nobel laureate V.S. Naipaul who discusses race relations between people of African and Indian descent in Trinidad in his book, The Middle Passage, published in 1962, the year Trinidad and Tobago attained independence from Britain. Naipaul writes:

It is sufficient to state that the antipathy exists. The Negro has a deep contempt, as has been said, for all that is not white; his values are the values of white imperialism at its most bigoted. The Indian despises the Negro for not being an Indian; he has, in addition, taken over all the white prejudices against the Negro and with the convert's zeal regards as Negro everyone who has any tincture of Negro blood. ' The two races,' Froude observed in 1887, 'are more absolutely apart than the white and the black. The Asiatic insists the more on his superiority in the fear perhaps that if he did not the white might forget

${ }^{33}$ According to the Dictionary of English/Creole of Trinidad and Tobago, a coolie is a person of East Indian descent , usually of the working class. Nowadays this term is generally considered " very negative and insulting." 
it. ' Like monkeys pleading for evolution, each claiming tobe whiter than the other, Indians appeal to the acknowledged white audience to see how much they despise one another. They despise one another by reference to the whites. (The Middle Passage 80)

Puri notes that in the Caribbean the belief in "the existence of distinct races withclearly distinguishable racial attitudes and characteristics raises pressing questions forTrinidadian nationalism. If, as Froude claims, and Naipaul concurs, 'the African' and 'the Asiatic' are so absolutely apart, then what does 'the Trinidadian' come to mean? Which races are included under the sign 'Trinidadian' and how do they compete for inclusion? How can the opposing characteristics of African and Indian be reconciled as 'Trinidadian'? How, in short, are racial character and national character reconciled ?" (Puri 2004 :174)

She points out that "the cultural centrality of calypso in Trinidad gives its construction of race wide currency and particular significance" and that "its prominence in Carnival has also given it a special role in the construction of identities and national memory." Noting that calypso and carnival are perceived to be "expressions of Afro-Trinidadian culture," she poses a pertinent question in respect to identity and race: "What does it suggest about the place of Indo-Trinidadians in the national imaginary that calypso has been seen as simultaneously AfroTrinidadian and national ?" She states that the importance of stereotype in calypso, combined with the racialization of politics in postcolonial Trinidad has resulted "in a situation in which stereotypes form the bedrock of public racial discourse," and that "what these stereotypes produce for dominant cultural national discourse is the fiction of a seamless and monolithic racial community with common interests, pitted against another seamless and monolithic racial community with common interests." ( Puri 2004: 183) 
Discussing stereotypes in calypso, several writers cite lyrics in which race and gender figure prominently. Puri, for example, refers to Indian People with Creole Names, ${ }^{34}$ a calypso sung in 1952 by Killer (Cephus Alexander).

Puri explains that the calypso raises concerns about issues of belonging and increasing /decreasing power of Indians in the national formation." (Puri 2004 :186). The following is an excerpt from that calypso:

What's wrong with these Indian people As if their intention is for trouble.

Long ago you'd see an Indian by the road

With his capra waiting to tote people load.

But I notice there is no more Indian again

Since the women and them take away Creole name.

Long ago was Sumintra, Ramnaliwia

Bulbasia and Oosankalia

But now is Enily, Jean and Dinah

And Doris and Dorothy.

Long ago you hadn't a chance

To see an Indian girl in a dance

But nowadays is big confusion

Big fighting in the road for their Yankee man

And to see them in the market they eh making joke

Knocking down nigger people to buy they pork

And see them in the dances in Port of Spain

They wouldn't watch if you call by an Indian name.

As for the men and them I must relate

Long time all they work was in cane estate

But now they own every theatre

Yes, hotel, rumshop and hired car

Long time was Ramkaisingh, Boodoo, Poodoo, and Badoo

Now is David,Cooper, Johnson,Caesar, Cephus Alexander.

\footnotetext{
${ }^{34}$ According to the Dictionary of English/Creole of Trinidad and Tobago, a creole is a person primarily of African descent and cultural-ethnic identification.
} 
Puri notes that Killer's calypso "fits squarely with the traditional usage of 'Creole' to refer to only West Indian whites, blacks and the mixed descendants of blacks and whites; this is a usage that has historically excluded East Indians, even though it claims to be a metaphor for Trinidadianess or West Indianess" and that "the comically evoked threat that creolized Indians pose" is that of "reducing the gap between self and other, and encroaching upon the terrain of the self." (Puri 2004: 186)

According to Puri, while Killer seeks "to protect his right to an Anglicized colonial name; a name that itself marks processes of hybridization and assimilation," he seeks "to exclude the East Indian from sharing that hybrid identity...He sees Indians not just as 'taking' Creole names but as 'taking away ' Creole names. Thus upwardly mobile creolized Indians are represented as literally knocking down the Creoles, taking their place, and appropriating their wealth." (Puri 2004: 187)

Puri notes that "the creolization of the Indian woman is identified in terms of a change in her sexuality. The stereotypical Indian 'girl' whose sexuality is strictly controlled by her family is now replaced by the creolized 'Emily, Jean and Dinah.' who go to dances and

She also cites a 1958 calypso by Lord Superior (Andrew Marcano), titled "Tax Them,"as another example of "the dominant Afro-Trinidadian national discourse."(Puri 2004: 184)

The following is an excerpt from the calypso:

Tax them doctor, tax them.

Tax them like you mad

Lord Superior say

Don't care who feel bad 
Down to the street girls

You should make them bawl

Check every Yankee man that they call

And buss tax on them and all

It have some old Indian people

Playing they like to beg

This time they got one million dollars

Tie between they leg

I am telling the doctor

I am talking the facts

Is to chop loose they capra ${ }^{35}$ with a sharp axe

And haul out your income tax.

Puri explains that the recurrent theme of Indian wealth is framed in this calypso "as a fear of Indian economic dislocation of Afro-Trinidadians, and a charge of Indian dishonesty. Indians are thus framed as robbing the nation. In this sense the calypso aligns Indians with British colonialists, framing both as exploitative intruders." The calypsonian also identifies the "street girls" or prostitutes "as homologous to the Indian man..." (Puri 2004 :185)

The "Indian's rise in politics," recorded in calypso, was also seen by Afro-Trinidadians as a threat to their control of the world that they knew, according to Constance in Tassa, Chutney \& Soca: The East Indian Contribution To The Calypso. (Constance 2002: 10) This led to what Constance describes as "the 'Indians taking over' syndrome" which he notes "became an obsession with some sections of the population." (Constance 2002 :30)

"Such was the propaganda in the African community, that even intelligent people believed that Indians were purposely making as many children as possible, children who could

\footnotetext{
${ }^{35}$ A capra is traditional Indian man's draped loincloth or trousers.
} 
be transformed into votes in the future," he states, quoting from another calypso by Killer which reflected "this then growing belief."(Constance 2002:30) Killer was singing about IndoTrinidadians who won seats in the 1950 general elections. The following is an excerpt from that calypso:

We going to all have the privilege

Trinidadians, to speak the Indian language.

Populations are growing so rapidly

Election time they win already

And as soon as they vote an Indian governor

Well the flag of India will be flying here.

Race became a major issue in the following general elections in 1956 in which the newly formed People's National Movement (PNM) came to power. The PNM drew its support mainly from Afro-Trinidadians and Afro-Tobagonians while the opposition People's Democratic Party (PDP), also newly formed, was largely supported by Indo-Trinidadians.

In the 1958 West Indies federal elections, the Democratic Labour Party (DLP), which was founded in 1957 and supported mainly by Indo-Trinidadians, defeated the PNM. The DLP won six of the ten seats in Trinidad and Tobago. Williams, the Afro-Trinidadian leader of the PNM who became the country's first prime minister, "responded bitterly" to the results of that election, "giving as the reason for the PNM's defeat, 'race, pure and unadulterated"' and describing the Indians "as a 'recalcitrant and hostile minority.'"Constance notes, however, that it was the 1961 general election campaign that "was filled with the most tension, terror, violent rhetoric and race talk and came closest to plunging the country into a racial civil war." (Constance 2002: 31) 
He states that the DLP had complained that "its 'people' had become the principal targets of Negro vandalism" and had reported "the stoning of mosques and temples, the looting of Indian homes and retail establishments, the beating of Indian venders, the slashing of tires on the cars of Europeans, the pulling down of DLP streamers, the breaking-up of election meetings, police brutality and the use of insulting expressions..." At the height of the campaign, Rudranath Capildeo, leader of the DLP, calling for open war on the PNM, demanded of his supporters thatthey arm themselves "with a weapon to take over this country." (Constance 2002:33).

Constance notes that "a limited state of emergency was declared ...and tensions diminished without blood being shed" (P. 33). After the PNM's victory at the polls in the 1961 general elections, calypsonians praised "the all-conquering" PNM and one of the singers, Nat Hepburn, "chastised and castigated" the DLP Opposition leader "for preaching violence where the PNM, this calypsonian contended, had demonstrated its astuteness and wisdom."

(Constance 2002:33).

He points out that Hepburn sang "'some deceitful people vote race,' not realizing or perhaps not wanting to admit that the African population who voted for the PNM was voting 'race' as much as the Indian population who voted DLP." This, he notes, was "something that was to remain a feature of the country's electoral politics up to the present time."(Constance

2002: 34$)$

In addressing the identity issue, people of African descent in Trinidad and Tobago, also got a critical look at themselves when calypsonian Maestro (Cecil Hume), presented his editorial in verse about black identity. The following is an excerpt from that calypso:

Presently almost everybody 
Talking about Black Identity

But if you check out the majority

They only using these words falsely

Because the first thing that is a shame

African people with European names.

That is the first step we have to take

To correct a prehistoric mistake.

If you hear Seecharan, Ramkhelwean, Lalchan, Balchan,

Well bet your life that is an East Indian man.

Jose, Juan, Gonzales, Manual, Sancho, Pancho

You sure them fellas from Mexico.

So why your name couldn't be Dingaka, Lumumba, Makeda or Kenyetta

If we use these names then we sure to be

On the stairway to true Black Identity.

If you retrace your steps from the start

You'll find names play an important part

For if you did some great thing in history

They might want to record your activity.

When you die they look on your tombstone

Is Adson, Jackson, Patterson, Calheam.

That is counterfeit identity

These people must be lost in world history.

Sirham, Birham, Ola Mehab, Babwah or Mustafa

Well you sure them fellas come from Arabia.

Rommel, Bruno. Adolph, Victoven, Von Eichmann

Bet your hand them boys is German.

So why your name couldn't be Mobuto, Kasavubu, Gowan or Oguku

Change your name from George Weekes to Wakamba

So we go know that you serious ' bout Black Power.

This calypso was one of several written by different composers in Trinidad around the

themes of "black power" or black pride following the uprising in the country in 1970 which was

called the "Black Power revolution." Although Maestro called on people of African descent to change their "European names," in order to identify themselves as Africans, he, an

Afro-Trinidadian, did not do so. However, many people in the country did take African names and have given their children such names.

In examining the issues of identity and race in Trinidad and Tobago one also has to take 
into account the country's growing dougla population. Puri notes the "fraught position" that the dougla occupies in post-colonial Trinidad which became the subject of a 1961 calypso by the Mighty Dougla (Cletus Ali) titled 'Split Me in Two,' recounting "the displacement of the dougla from dominant discourse of race." (Puri 2004:191). The following is an excerpt from the calypso:

Some fellas having a race discussion;

I jump up to give my opinion.

A fellow watched me in meh face;

He say 'you, shut your mouth, you ain't got no race.'

What he said to me was a real insult

But is not me to blame, is meh father fault.

When he say I have no race, he ain't talking true.

Instead of having one race, you know I got two.

Because they sending Indians to India

And the Negroes back to Africa

Can somebody just tell me

Where they sending poor me

I am neither one nor the other

Six of one, half a dozen of the other

If they serious about sending people back for true

They got to split me in two.

According to Puri, "'Split Me in Two' stages the "social and cultural displacement" of the dougla, who is "literally silenced in those early 'race discussions."' (P. 191) She notes that the calypso ends with the singer "refusing to be labelled raceless and refusing, equally, to be forced into choosing one race or another." (Puri 2004: 191-192)

In Governing Sound: The Cultural Politics of Trinidad's Musics, Jocelyne Guilbault, a professor in the Department of Music at the University of Califonia, notes that the song, Split Me in Two, was "soon to be forgotten" in a society "marked by political division between blacks and East Indians." She states that "from independence to the late 1980s, the nationalization of 
Carnival and calypso competitions and the establishment of competition regulations deployed as political technologies to build a unitary national culture did little to address the historical erasure of either the dougla or the non-Afro-Trinidadian ethnic groups." (Guilbault $2007: 52$ ).

Guilbault notes that the first prime minister of the independent state of Trinidad and Tobago proceeded to "nationalize Carnival and calypso." She explains that the state government set up its "Carnival Development Committee, appointed the Committee members - usually people who were members of, or had some other close relations to the ruling political party and promised financial help with the prizes." (Guilbault 2007:48)

She states that "by preventing migrant artists from entering competitions, excluding songs with too many 'outside' influences from being selected in the semi-finals, and admonishing artists from going 'astray' with their diasporic sensibilities, these formal and semi-formal disciplinary measures sought to produce a musical scene articulating an isomorphism between people, place and culture." She explains that these measures "effectively worked to reinforce borders, identify citizens as those rooted in the land, and construct culture as emerging only from the nation-state." (Guilbault 2007: 51)

Guilbault notes that "for Afro-Creole middle-class intellectuals and for politicians of the then-ruling People's National Movement, calypso was the artistic expression that best presented Trinidad's worldview - even though it embodies a male Afro-Trinidadian perspective." The Creole middle-class "associated calypso with the process of cultural identification and political emancipation - at least, it should be stressed, for members of the Afro-Trinidadian diaspora and of the Creole middle-class then forming the leading social activists and political leaders of the country." (Guilbault 207:49) 
" Concomitantly, this mapping of the nation-state, its people and culture helped reinforce at least three disavowals: that the local population of Trinidad and Tobago was itself constituted through transnational migration, that the nation-state encompassed many different types of subjects in terms of race, ethnicity, religion, sexual orientation, gendered roles and so on and not all people rooted in the land enjoyed equal rights as citizens; and that the cultural phenomenon celebrated - calypso - also proceeded from transnational fusion," she states. (Guilbault 2007 :51)

In discussing the issue of race in The Political Calypso: True Opposition in Trinidad and Tobago -1962-1987, Regis points out that "all but one of the major calypso controversies since independence have had to do with race relations" and that "several songs have been condemned as being disrespectful, divisive, insulting, mischievous, misleading, prejudicial, prejudiced, racial, racist and or all of the above. Happily, these negative designations do not hold good for most calypsos," (Regis 1999: xi)

However, it can take just one calypso to create widespread feelings of discord in the country. One song which sparked a great deal of racial controversy when it was first sung in 1979 was Caribbean Unity, a composition of Stalin (Leroy Calliste), a five-time winner of the coveted annual calypso monarch competition. The following is an excerpt from his song:

You try with a Federation

The whole thing end in confusion

Caricom $^{36}$ and then CARIFTA ${ }^{37}$

\footnotetext{
${ }^{36}$ CARICOM is the acronym for the Caribbean Community, an organization of 15 Caribbean nations and dependencies. Among its major objectives is the economic development and convergence of its members. CARICOM was established in 1973.

${ }^{37}$ CARIFTA is the acronym for the Caribbean Free Trade Area which was superseded by CARICOM in 1973.
} 
But somehow I smelling disaster.

Mr. West Indian politician

You went to big institution

How come you cyah unite seven million

When a West Indian unity

I know is very easy

If you only rap to your people

And tell them like me.

Dem is one race - De Caribbean Man

From the same place - De Caribbean Man

That make the same trip - De Caribbean Man

On the same ship - De Caribbean Man.

So we must push one common intention

For a better life in the region

For we women and we children.

Despite its title, the song was condemned as racist by a major Hindu organization in Trinidad, a lecturer at the University of the West Indies and many others. Yet others spoke out in defence of the song.

Constance notes that Dr. Ramesh Deosaran. a former lecturer in psychology at the University of the West Indies, complained that it "pushes the view that only people of African descent are entitled to take part in Caribbean unity" and that "this was nothing less than a grossinsult to the vast number of people of other races who had come in different ships from different places." (Constance 2002: 62) However, Guilbault cites Hollis "Chalkdust" Liverpool who argued that the song "counts West Indians among the 'all of us' ...from Africa, India, Syria, Jerusalem or Portugal who have had common backgrounds of toil, travel, alienation, depersonalization, dehumanization..." (Guilbault 2007: 99)

According to Regis, songs such as Caribbean Unity act like what cultural theorist Stuart Hall calls "'maps of meaning' into the geography of a complicated political culture."(Regis 1999: xi) In Representation: Cultural Representations and Signifying Practices, Hall explains that "just as people who belong to the same culture must also share a broadly similar conceptual map, so 
they must also share the same way of interpreting the signs of language, ${ }^{38}$ for only in this way meanings can be effectively exchanged between people."( Hall 1997 :19)However, this raises questions. Hall asks:" How do we know what concept stands for which thing? Or which word effectively represents which concept? How do I know which sounds or which images will carry through language, the meaning of my concepts and what I want to say with them to you?" (Hall $1997: 19)$

In 1995, Basdeo Panday became the country's first Indo-Trinidadian prime minister and the target of several calypsos, some of them racist. One calypsonian called Cro Cro (WestonRawlins) blamed Afro-Trinidadians for voting for Panday who had been charged with sexual harassment but was acquitted of the charges soon after assuming office. The following is an excerpt from Cro Cro's calypso titled All Yuh look for That:
Ah man on a charge of interfering
Black man all you still go and vote for him
Imagine this sex sliver headed pest
Put he fingers under your daughter dress
Me eh saying that Patrick ${ }^{39}$ shoulda win, Sah
But even Jim Baker would be better...
Black man all you look for that. All you look for that

Cro Cro reacted angrily when he was told by another calypsonian, Chalkdust (Hollis Liverpool), who was then director of culture in Trinidad and Tobago, that he could not sing his controversial All Yuh Look for That at a folk fair. (Constance 2002:57) The following is an excerpt from Cro Cros's response in song:

\footnotetext{
${ }^{38}$ Calypso (words and music) is language within Hall's broad definition of the term. He describes music as " language with complex relations between different sounds and chords."

${ }^{39}$ The Patrick mentioned is Patrick Manning who was the leader of the People's National Movement (PNM).
} 
Commentary music must remain in calypso

Raise your hand and support Cro Cro

Who the hell tell them commentary must go

Raise your hand and support Cro Cro...

Cause if we sit back and let these bitches control the art form

Calypso gone! Calypso gone!

Constance notes that during Panday's first five-year term of office as prime ministe" Calypsonians attacked left, right and centre. . Panday found himself on the end of the Calypsonians 's music stick" and had promised that "state funds would not be used to promote racists and divisive songs." Constance states that "the threat, real or imagined, that the government wished and intended to censor the calypso brought vehement reaction in the Calypso community ..." (Constance 202: 57)

He notes, for example, that Luta ( Morel Peters), a calypsonian who "championed Panday's ascension in 1995," demanded in one of his calypsos that he (Panday) "pack up and go."(Constance 2002: 58). The following is an excerpt from that calypso:

If for some reason Calypso making you blue,

Listen to me carefully, I have some advice for you.

If the ills of society is reflected in Kaiso

And you cyah take the jamming

Pack up your things and go."

However, despite Panday's threat to cut off state funds for calypsos that promote racism and divisiveness, his government, to its credit, did not re-introduce censorship.

Turning to issues of gender, Gordon Rohlehr, in Calypso \& Society in Pre-Independence Trinidad, notes that "it was assumed in calypso that women were naturally fickle and unfaithful " and that "the female 'coping' strategy of having several spouses over a period of time, some of 
whom might help finance a relationship" reinforces the stereotype ofthe 'naturally promiscuous' female and the corresponding male ideal of eternal bachelordom." (Rohlehr $1990: 222)$ "On the other hand, many women were as mistrustful- and wisely so - of entering into any binding relationship with unreliable men who would try to control their income and limit their independence, as the men were fearful of taking responsibilities of husbandhood which they could not fulfil. So there was a joint reluctance to enter into, and a mutual distrust ofbourgeois conjugality even when this was viewed as a desired ideal"(Rohlehr 1990 :222)

While many calypsonians sang in praise of motherhood and of the beauty and desirability of some women, Atilla the Hun "jealously warned men about women's trespassing on male preserves of power and prerogative." (Rohlehr 1990: 223) The following is an excerpt of one of his calypsos of 1935 titled "Women Will Rule The World":

I am offering $a$ warning to men this year Of modern women beware (Twice). Even the young girls you cannot trust For they're taking our jobs from us. And if you men don't assert control Women will rule the world.

Rohlehr notes that "the fact that Atilla sang at least three calypsos on this theme should suggest that he took the matter of competition between the sexes very seriously indeed. He thus became the mouthpiece of some of the most reactionary, anti-feminist ideology, and the spokesman for a rigid patriarchy that was incapable of transcending the narrow sexism of the age." (Rohlehr 1990 : 224)

Political correctness may have been slow on entering the calypso stage but fewer songs which are racially offensive or insulting to women are now heard at public performances. To a 
large extent, the reasons may be economic, especially since managers of calypso tents are heavily dependent on government funding. The present government, headed by Prime Minister Kamla Persad-Bissessar, which came to power with major support from Indo-Trinidadians and women from both major races, is not expected to allow taxpayers' money to be used to promote racially offensive songs and those that denigrate women.

During the 2014 carnival season, Cro Cro, widely known for his compositions whichare offensive to Indo-Trinidadians, complained that his calypso tent was denied government funding. Another calypsonian known as Sugar Aloes (Michael Osuna) whose tent did receivegovernment funding, was criticised by Cro Cro for refusing to allow a calypsonian to sing in his (Osuna's) tent a composition that Sugar Aloes found to be racially offensive. (Chapter six) Osuna was himself known for his racially inflammatory calypsos but has recently stopped singing such songs.

As calypso continues to evolve in a contested cultural environment, the presence of more women on the calypso stage is a positive development. Although outnumbered by men, the female calypsonians are raising their voices against the denigration and oppression of women and are also singing on other significant social issues.

In summary, this chapter explores issues of identity, race and gender in multicultural Trinidad and Tobago where calypso is widely regarded as a national art form. It is also perceived as an expression of the people of African descent, one of the two major racial groups in the country, the other being people of Indian descent.

Tracing racial stereotypes in Trinidad from the colonial period, this chapter discusses relations between people of African and Indian descent in Trinidad and Tobago and examines 
political developments in the two-island state from the 1950 s to the post-independence period. It also looks at the situation of the country's growing dougla population.

The "Indian's rise in politics" in the 1950s was seen by Afro-Trinidadians as a threat to their control of the world that they knew and this led to what has been described as "the 'Indian taking over"' syndrome which "became an obsession with some sections of the population."

In their discussion of the race issue, several authors quoted in this chapter have cited calypsos, many of which have promoted negative stereotypes of people of Indian descent and have denigrated women.

With respect to the gender issue, the accession of more women onto the calypso stageis seen as a positive development. Female calypsonians are singing on a wide range of issues, including those that directly affect them.

The following chapter discusses restraints to freedom of expression in calypso in the post-independence period in Trinidad and Tobago- unofficial censorship and self-censorship. 


\section{Chapter Six}

\section{UNOFFICIAL CENSORSHIP AND SELF-CENSORSHIP}

Since censorship under the Theatres and Dance Halls Ordinance ended in 1951, calypsonians in Trinidad and Tobago have not enjoyed unfettered liberty in presenting their "editorials" in rhythm and rhyme. Apart from the prevailing laws of libel and slander, in effect long before the period of official censorship of calypso, they have been facing other restraints. Local radio and television stations keep certain songs off the air and like the electronic media, calypso tents impose their own controls on freedom of expression. In the current postindependence period, these restraints, which this thesis describes as unofficial censorship, along with self-censorship, have become an issue of growing concern for the future of calypso.

This issue is rooted in economic as well as political factors. Radio and television stations, which obtain their operating licenses from government have from time to time blocked airplay of songs which were considered offensive to various groups in the society. ${ }^{40}$ Tents which are government-subsidized, have at times tightened the reins on singers of political commentary to avoid offending the source of their funding. As Chalkkdust (Hollis Liverpool), an eight-time winner of the annual Trinidad and Tobago calypso monarch competition, noted, some singers in the tents may be required to change a verse, "soften" a verse or leave it out entirely. ${ }^{41}$

Both unofficial censorship and self-censorship became an issue of considerable discussion in 2014 while the calypso tents were in operation in Trinidad. Pitted at the centre of a

\footnotetext{
${ }^{40}$ Some calypsoes which are considered smutty or morally offensive have been kept off the local airwaves.

${ }^{41}$ Interview with calypsonian Chalkdust (Hollis Liverpool), August 8, 2014
} 
calypso controversy were Michael Osuana, the 2002 calypso monarch of Trinidad and Tobago who sings under the name of Sugar Aloes and is the manager of the Kalypso Revue tent, and Roger Mohammed, a policeman, who is known onstage as Bodyguard.

For many years, Sugar Aloes was one of the darlings of the Afro-Trinidadian-based People's National Movement (PNM). He sang calypsos which were offensive to IndoTrinidadians. But to the surprise of many calypso aficionados, he took a decision not to allow Bodyguard to sing at the Kalypso Revue tent because of his (Bodyguard's) song titled False Papers. This calypso was about people of Indian descent with bogus academic credentials. Sugar Aloes found the song to be racist, unfairly targeting the Indo-Trinidadian community. ${ }^{42}$ The following is a brief excerpt from False Papers:

So you tell me, how so much Indian people get caught?

Wid false papers, false papers

While conversely, not one African in the lot

Plenty black people study and work hard for what they got.

Commenting on his rejection, Bodyguard said that Sugar Aloes had no moral authorityto talk about racism and accused him of displaying double standards. ${ }^{43}$ In an interview with Bodyguard as part of the research for this thesis, he explained why he criticized Sugar Aloes for rejecting him. ${ }^{44}$

"He (Sugar Aloes) chose to go on national television and accuse me of attacking a race of people. That was hypocrisy of the highest order," said Bodyguard who noted in the interview that Sugar Aloes and another calypsonian, Cro Cro (Weston Rawlins), also a strong supporter of the PNM, "literally ran East Indians out of the calypso tents" with their songs.

\footnotetext{
${ }^{42}$ Kowlessar, Geisha "Aloes rejects 'race' song " Trinidad Guardian, January 15, 2014 P.3A ${ }^{43}$ Ibid

${ }^{44}$ Interview with calypsonian Bodyguard (Roger Mohammed), December 28, 2014
} 
Bodyguard recalled the days when the tents were well patronized by people of Indian descent. But he said that was no longer the case "after the United National Congress (UNC)won the general elections in 1995 and Basdeo Panday, an Indo-Trinidadian, became prime minister. Sugar Aloes and Cro Cro then went on a rampage against East Indian people. Panday, his wife and others were in the firing line."

Responding to attacks in song on Indo-Trinidadians, Panday who served as prime minister of Trinidad and Tobago from 1995 to 2001, had threatened to cut off state funds to calypsonians but he did not carry out this threat. As he explained in an interview, calypsos were being used to "drive a wedge" between the races in the country and state funds should not be used "to promote racism...There are people of Indian descent who pay taxes and their taxes should not be used to denigrate them."

Bodyguard claimed that Sugar Aloes has "switched allegiance" ${ }^{46}$ from the PNM, now in the opposition, to the current coalition People's Partnership government of Prime Minister Kamla Persad-Bissessar, also an Indo-Trinidadian. He noted that about two years ago [2012], Sugar Aloes went on a "People's Partnership political platform" and serenaded Prime Minister PersadBissessar with a song titled "She's Royal." He said that since then, the calypsonian-tent manager has not sung "anything criticizing the government." In other words, according to Bodyguard, Sugar Aloes has been practicing self-censorship.

A corporal in the Guard and Emergency branch of the Trinidad and Tobago Police Service, Bodyguard said that after his song was rejected by Sugar Aloes, he got a chance to sing

${ }^{45}$ Interview with former Trinidad and Tobago prime minister Basdeo Panday, January 6, 2015 ${ }^{46}$ Sugar Aloes is not known to have declared his allegiance to the government of Prime Minister Persad-Bisssessar. According to reports in Trinidad newspapers, he explained that his performance on a People's Partnership platform was " just a job." 
at another tent which was managed by Cro Cro, now a severe critic of Sugar Aloes. That tent which did not receive government funding, was in operation for a short period during the carnival season.

Commenting on the False Papers issue, Cro Cro said that Sugar Aloes "has the right as a tent manager to reject anybody, but he cannot pontificate on calypso. His reason for blanking the man [Bodyguard] is disrespectful and wrong." 47

Bodyguard said he felt vindicated on the False Papers issue when he was selected forthe finals in the Trinidad and Tobago 2014 calypso monarch competition. False Papers was one of the two songs which he sang at the competition. He is deeply concerned, however, about censorship in whatever form which he sees as "a threat to calypso". He said "the threat is becoming worse. The tents are no longer making the money that they used to make years ago and will continue to be dependent on government funding."

From a marketing point of view, promoting songs, which are racially offensive has a negative impact on the music industry in Trinidad and Tobago. But Bodyguard, himself of mixed race, had no qualms about his attack on Indo-Trinidadians in False Papers. Asked whether he considered the song "fair comment," he remarked: "Whether it is fair or unfair is subjective, to mind." In defence of False Papers, he explained that what he sang about was based on reports published in the local newspapers. However, press reports, while they did name names, did not identify persons with questionable or false credentials as belonging to a specific race.

While the False Papers issue is one of the more recent examples of unofficial censorship, it is to be noted that earlier, during the PNM administration, calypsonians practiced self-

${ }^{47}$ Blood , Peter Ray "More blows for Sugar Aloes over Bodyguard snub," Trinidad Guardian January 16, 2014 P. 3A 
censorship and also had to deal with unofficial censorship of one kind or another. Quotingthe Trinidad Guardian newspaper, Louis Regis, in his book, The Political Calypso: True Opposition in Trinidad and Tobago $1962-1987$, notes that in 1957, one year after the PNM came to power, "there was not an anti-government calypso in sight." (Regis 1999:4).

Clearly, after just one year in office, the PNM government could not have solved all the problems in the country. There must have been in 1957 some societal concerns which called for "editorial comment" in song. Later, during the years of PNM rule, some songs which criticized the government were either not broadcast on the local airwaves or given little airplay.

Although the PNM government did not re-introduce censorship laws as such, party supporters responded harshly to calypsonians who dared to sing political songs which criticized Prime Minister Dr. Williams and his government - sometimes with serious consequences for the singers in question. A striking example was Chalkdust (Hollis Liverpool) who in 1968 sang Brain Drain which criticized Dr. Williams. Chalkdust found himself out of a job. He was fired from the teaching service. (Chapter nine)

The "official" reason given for his dismissal had nothing to do with the song itself. He was sacked because he was earning money as a calypsonian while employed as a teacher. Under legislation from the colonial past but still on the books, public servants are prohibited from holding more than one job. Chalkdust fought against his dismissal in song and was reinstated in his teaching position. In 1973, he sang another song, Somebody Mad, in which he again criticized the prime minister. Some women in the PNM complained about the song but the prime minister told then: "Let the jackass bray." Chalkdust defied his opponents and has continued to 
sing political songs. The same is not true of many calypsonians whose voices as political commentators are hushed or diminished by self-censorship.

In 1980, another calypsonian, Lord Relator, had the temerity to call on the ruling PNM and Prime Minister Eric Williams to "Take a rest" in one of his songs at the monarch competition. Lord Relator won the crown that year but understandably, his song was not well received by PNM supporters. The following is a brief excerpt from Take a rest:

No Light, no Telephone and no Water

We in the middle of a big power failure.

I am sorry that the breakdown is governmental

And is because of fatigue, physical and mental.

Is useless that we continue to blame

A horse that is tired and almost lame.

If government cannot cope nowadays,

The nation should send them for holidays.

Now this is not ah overthrow

I eh saying we should kick them out just so.

So please don't jump to any hasty conclusion

And cause any confusion (Oh Yes)

But they exhausted from working too long

So before they suffer from a nervous breakdown

As a loving nation, we all could now suggest

That Dr. Williams and the PNM take a rest.

Later, in 1980, when Dr. Williams took a trade mission to the Far East, Lord Relator was excluded from the official delegation. It was the usual practice to include the reigning calypso monarch on such a trip. The following year Lord Relator retaliated with China Syndrome, a song accusing the PNM of petulance. Since then Lord Relator has not competed for monarch title. Neither has he presented any more songs about political matters in the country. Although he still performs on the calypso stage, he is one of a growing number of the local bards who are now believed to have opted for self-censorship. 
As Keith Warner notes in Kaiso! The Trinidad Calypso: A study of Calypso as oral literature, "when least expected, the unofficial and self-imposed censorship by the radio station rears its head." He cites as one example the refusal of a radio station to provide airplay for a calypso by Short Pants (Llewellyn MacIntosh) titled The Law is an Ass. Warner states that it is "only after increased pressures that it was allowed to be heard...There was nothing offensive in the calypso." (Warner 1999: 69) The following is an excerpt from The Law is an Ass:

\author{
I want to see \\ Justice shine out in this country. \\ This ain't no fun; when cases are won \\ We must feel that Justice is done (it must be). \\ Don't care how big; don't care how small \\ The law must be there for all - but \\ If Judges are taking bribe \\ To throw your cases outside, then \\ The law is an Ass. \\ If when your cases call \\ No papers at all, then \\ The law is an Ass. \\ If policemen, indeed \\ Selling and smoking weed, then \\ The law is an Ass and \\ If the brillant $A G$ let all these things pass \\ We know the law is an Ass.
}

Commenting on the unofficial censorship in 1979 of The Law is an Ass, Short Pants noted that it came not just from a radio station (Radio 610) and the local television station (Trinidad and Tobago Television) but from the Calypso Revue, the tent in which he was singing. ${ }^{48}$

He said he was "encouraged" to write the calypso by a good friend, a lawyer, " who

${ }^{48}$ Personal correspondence with Llewellyn Mac Intosh, July 10, 2014 
had been disappointed by the [legal] system" and that after its first performance in the tent, the song "took off." He later added a number of stanzas, attacking those "who had troubled me for my composition of the calypso" but noted that the song had been given "a clean bill of health" by his lawyers. He recalled that censorship of the song which he angrily opposed, "lasted only one night" in the tent.

By 1986, several calypsonians and writers of calypso lyrics were hired by the major political parties in the country to produce campaign songs for the general elections that year in which the coalition National Alliance for Reconstruction (NAR) won a landslide victory. The NAR won 33 of the 36 seats in the House of Representatives, defeating the PNM which had been in power for three decades. The remaining three seats went to the PNM.

The success of the NAR at the polls was attributed in no small measure to the political messages in the calypsos heard on the campaign trail. Some were written as campaign songs while others were calypsos appropriated for the campaign. For example, The Sinking Ship, sung by Gypsy, was not written as a campaign song but as a political calypso and it became a very popular campaign song. More than 30 years after it was first sung, it remains one of the most outstanding political songs in the history of calypso.

Since 1986, growing numbers of composers and artistes in Trinidad and Tobago are engaged in producing political campaign songs and as singer and comedian Sprangalang (Dennis Hall) said in an interview, political commentary in calypso has to a large extent become partisan political commentary. ${ }^{49}$

${ }^{49}$ Interview with calypsonian Sprangalang (Dennis Hall) January 20, 2015 
Sprangalang, a former president of the Trinbago [Trinidad and Tobago] Unified Calypsonians Organization, who is well versed in calypso lore, noted that political songs used to be "more broad-based" and the calypsonians "would say 'this wrong, that wrong, that wrong' and they used to question the political and moral authority of the administration. Nowadays many of them are just repeating the stuff political parties are saying." Describing the partisan songs as "bad journalism masquerading as calypso," he warned that these songs "will destroy the art form. ${ }^{50}$

Some calypsonians came to be seen as agents of propaganda after singing in support of apolitical party or doing radio and television commercials for that party. Once calypsonians were identified with a particular party, they were not likely to criticize that party in song. Some calypsonians who sang against the PNM, found themselves the target of criticisms from some of their colleagues and calypso aficionados.

One calypsonian who said he was targeted was Crazy (Edwin Ayoung) who sang against the PNM in the general election campaign in Trinidad and Tobago in 2010. He said that after he sang "Manning must go," a calypso criticizing Patrick Manning who was then prime minister and political leader of the PNM, he received death threats and "people cursed me and threatened to burn down my house. ${ }^{51}$

"But they will not stop me from singing against the PNM," he declared.

Crazy said that since the PNM was launched in the 1950s, its followers have behaved as if they were the sole owners of calypso. He recalled that for more than 20 years he sang at one of the calypso tents "which was controlled by the PNM.

${ }^{50}$ Ibid
${ }^{51}$ Interview and personal correspondence with Crazy (Edwin Ayoung), 
"You couldn't sing a song criticizing the PNM in that tent."

Writing in the Trinidad Express, one of Trinidad and Tobago's daily newspapers, Terry Joseph, a close observer of calypso developments, had warned during a general election campaign in 2000 that calypsonians were muzzling themselves. Joseph noted that calypsonians who preach " independence of thought" were " fiercely chastising those among them that practise it." He wrote: "In the latter-day world of calypso, the definition of political commentary has apparently been narrowed to mean audible support for the People's National Movement (PNM), or alternatively, denigration of the United National Congress (UNC). ${ }^{52}$

Joseph went on to note that "calypsonians who dare deviate from this unwritten rule have discovered, to their chagrin, the degree of ostracism that such adventures may incur. At every sequence, Gregory 'GB' Ballantyne and stable-mate M'ba are being rebuked by their colleagues, on the flimsy evidence that they sang songs in praise of the UNC." He also noted that former national calypso monarch, Gypsy, who went "one step further by offering himself as a UNC candidate, " had become "an even larger target, all because he either changed his political allegiance, or only now decided to make it public..." 53

Joseph pointed out that "what the pro-PNM calypsonians are quite inadvertently doing, is curtailing freedom of expression, the very concept that allows them to sing songs favourable to their preferred political party. Such naivete is not only perilous in the present tense, but is bound to impact on the future of the very art." ${ }^{54}$

\footnotetext{
${ }_{52}^{52}$ Joseph,Terry "Calypso Muzzling Itself" Trinidad Express, November 22, 2000 P. 16 ${ }^{53}$ Ibid

${ }^{54}$ Ibid
} 
According to Joseph, "if the perception of the PNM is one of an African-Trinidadian party, then calypso is further narrowing potential earlier reduced through decades of denigrating women, bashing the gay community and hurling abuse at other ethnic groups and the elite. In the sum, calypso seems to be working harder than ever at shrinking its already miniscule market." He suggested that " if calypsonians really wish to guard the precious facility of singing unfettered by political interference, then all must be allowed to air their views. And while that may not please a few , it would undoubtedly redound to the greater good of the art." 55

Sprangalang has predicted that by 2020 there will be "no such thing as calypso," ${ }^{56}$ as soca continues on the ascendancy. This thesis makes no such prediction but there is growing evidence, as cited in this chapter that unofficial censorship and self-censorship continue to impact negatively on calypso as a vehicle for political commentary, making this musical genre an endangered species.

The following chapters - from seven to fourteen - are profiles of calypsonians interviewed, many of them former calypso monarchs. In the interviews, the artistes discussed various aspects of calypso and assessed the challenges facing the art form as a vehicle for political commentary.

\footnotetext{
${ }^{55}$ Ibid

${ }^{56}$ Interview with calypsonian Sprangalang (Dennis Hall), January 20, 2015
} 


\section{Chapter Seven}

\section{THE MIGHTY SPARROW (SLINGER FRANCISCO)}

Bouncing back from a coma in which for several days his life lay precariously in the balance, a reflective Mighty Sparrow (Slinger Francisco) spoke of his career as a singer spanning more than four decades. He also noted the challenges facing the musical genre in which he has earned an international reputation as "calypso king of the world."

His prognosis for the future was not entirely promising. Asked specifically whether political commentary in calypso was a dying art, the 80 -year old artiste said: "I would think so.It looks that way."

The Mighty Sparrow who lives in New York, was born in the fishing village of Grand Roy in the Caribbean island of Grenada. When he was one year old, he was taken by his mother to Trinidad where his family settled. It was in Trinidad that he started his singing career after learning songs from gramophone records at home and serving as a choirboy at a Roman Catholic church in Port of Spain where he sang both in Latin and English.

From the church choir to the calypso arena was a major move for the aspiring artiste at a time when the singing of calypso was frowned upon by the church and many others in colonial Trinidad. But the Mighty Sparrow noted that even as a nervous youngster who couldn't stand still onstage at the calypso tent and kept "moving around from side to side," as he sang, he got "a good reception" from the audience.

He recalled that at that time "well-established" calypsonians would stand before the microphone and "deliver their lines without moving around" and that they chided him for his 
style of singing. "The Growling Tiger [Neville Marcano] told me that I was jumping around thestage like a Sparrow."

"This might have been said jokingly but the name stuck," he laughed. At first he was called Little Sparrow but he later took the "Mighty Sparrow" as his stage name.

It was as the Mighty Sparrow that the singer-songwriter-guitarist and one-time pan player ${ }^{57}$ went on to become the "calypso king of the world." Not only does he hold the record, along with Chalkdust (Hollis Liverpool), for winning the Trinidad and Tobago calypso monarch title no fewer than eight times but he has twice won the Calypso King of Kings contest in which various calypso monarchs competed. He is also the only artiste to have won both the Trinidad and Tobago calypso monarch title and the Road March in the same year three times.

The Mighty Sparrow who was awarded an honorary doctorate of letters from the University of the West Indies in 1987, is also the holder of three Trinidad and Tobago national awards, including the country's highest - the Order of the Republic of Trinidad and Tobago which he received in 2014.The other two are the Humming Bird Medal (Silver) which he received in 1969 and the Chaconia Gold Medal, in 1995. He also received many other awards from various governments and organizations, including the honorary Yoruba title of Chief OmoWale of Ikoyi at the Second World African Festival of Arts and Culture in Nigeria in 1977 and the Order of the Caribbean Community in 2001.

His ascendancy to the calypso pantheon can be traced back to 1950s soon after he made his debut at the Old Brigade tent in Port of Spain. In 1956, two years after he started singing

${ }^{57}$ A self-taught guitarist, the Mighty Sparrow also learned to play the steel pans. As a teen-ager, he joined a steelband comprising boys from his neighbourhood in Port Of Spain and performed with the band at the carnival. 
there, he won the Trinidad and Tobago calypso monarch title for the first time with YankeeGone, better known as Jean and Dinah, one of his most memorable songs, which was also the Road March at the carnival that year. The Mighty Sparrow who has produced more than 70 albums (more than 600 songs) has performed in various cities in Europe, Asia, Africa, North and South America and in the Caribbean.

From his early years as a calypsonian, the Mighty Sparrow supported the then newly formed political party, the People's National Movement (PNM), headed by Dr. Eric Williams. Like several other calypsonians, he sang in praise of Dr. Williams and the PNM which came to power in 1956. His political songs in favour of the PNM government earned him the reputation as a major mouthpiece for the party and the government. But by the 1960s, he was singing calypsos which le some to believe that he had become disenchanted with the PNM and had switched his support to another party.

Not so, said the Mighty Sparrow. When asked about the shift in his political allegiance, as was reported in the media in Trinidad and Tobago, ${ }^{58}$ he flatly denied that he had "changed sides." He said, though, that in some of his songs he had made critical comments about various situations in the country, such as rising food prices.

"I was always concerned about food prices because as a young man, I could not afford to go to the grocery and buy this, that and the other. My family was very poor."

He conceded that his critical comments would have displeased "certain people." He was referring mainly to people in government.

${ }^{58}$ According to reports in Trinidad and Tobago newspapers, the Mighty Sparrow had shifted his support from the People's National Movement to the now defunct Organization for National Reconstruction, headed by his attorney, the late Karl Hudson-Phillips. 
Discussing the challenges currently facing calypso, he noted that fewer calypsonians today are singing about serious issues affecting the development of the society. "They are more into the party mood, not offending anybody and having a good time singing about what we are going to do in the party and enjoying themselves," he remarked.

However, he remains convinced that calypso as a vehicle for political commentary can effect change in the society. "I think it can. It all depends on the topic," he said.

The Mighty Sparrow whose song Congo Man ${ }^{59}$ was banned from airplay by local radio stations, has strong views about the "banning of songs." "That is something that must be taken very seriously. You don't want that to stand in your way after you have gone through the trouble of coming up with a good calypso."

He also expressed concern about insufficient airplay of calypsoes, "especially nationbuilding songs" on radio stations in Trinidad and Tobago which are not subject to any local content regulation with respect to music.

"Since calypso is the music of Trinidad and Tobago, the local radio stations should make a point of playing the nation-building songs. In fact, the stations should be required to play these songs as one of the conditions of obtaining their licenses," he suggested.

In recent years, the Mighty Sparrow has been experiencing health problems. He has been hospitalized on more than one occasion for complications caused by diabetes. In September2013, while in a coma for several days in a New York hospital, calypso fans watched and prayed as the

\footnotetext{
${ }^{59}$ Congo Man, a popular song about cannibalism with sexual innuendoes, first sung in 1965 , was banned from radio airplay in Trinidad for several years.
} 
life of the world's most celebrated calypsonian lay in the balance and rumours of his demise went viral on social network.

But the Mighty Sparrow has recovered sufficiently to be able to get back onstage.

While he is not "jumping around" as he did when he started out at the Old Brigade tent in Port of Spain in the 1950s, he continues to entertain his fans with his versatility and showmanship, belting out many of his popular "oldies." 


\section{Chapter Eight}

\section{CHALKDUST (HOLLIS LIVERPOOL)}

University lecturer, historian and calypsonian Hollis Liverpool, who sings under the name Chalkdust, was once described as a "jackass" by Trinidad and Tobago's first prime minister, Dr. Eric Williams. The late prime minister had come under attack, though not named, in Chalkdust's song titled Somebody Mad.

The exact quote attributed to Dr. Williams: "Let the jackass bray." ${ }^{60}$

In response, Chalkdust sang another calypso called Let the jackass sing. ${ }^{61}$

Decades after he belted out that number, which is reported to have drawn laughter from Dr. Williams, Chalkdust has continued to sing hard-hitting political calypsos. He is highly regarded as a master of the art form and holds the record with the Mighty Sparrow (Slinger Francisco) for having won the Trinidad and Tobago national calypso monarch title no fewer than eight times.

Chalkdust who received a Trinidad and Tobago national award (the Humming Bird Medal - Silver) in 1976 for his contribution to calypso, was born in Chaguaramas in Trinidad's north-western peninsula in 1941. He wrote his first calypso in 1954 while he was a student at St. Mary's College, a prestigious Roman Catholic secondary school for boys in Port Of Spain.

60 "One Caribbean: Dr. Eric Williams on Carnival, Culture and Development" 26th Annual Eric Williams Memorial lecture May 28, 2007 P. 2

61 The calypso was titled PNM Women but was more popularly known as Let the jackass sing. 
During the 1960s, while teaching at a primary school, he started singing professionally. To date, he has produced 28 albums.

Recalling his early days as a calypsonian when he ran into problems with Eric Williams' ruling political party, the People's National Movement (PNM), Chalkdust said that he was "never against the PNM.

"There might have been things that they did that I didn't like but I did not attack the PNM as a group or as a party."

As he explained: "I was attacking the evils in the society." But clearly, his lyrical attacks on many of these "evils" were seen as direct salvos fired at the PNM government.

So when he sang Somebody Mad in 1973, some women in the PNM complained to the prime minister who replied with his dismissive "let the jackass bray" comment.

Earlier, under the Williams-led PNM government, Chalkdust was fired from his teaching position after he sang Brain Drain, a calypso which criticized Dr. Williams. The official reason given for his dismissal had nothing to do with the song itself. He was sacked under an old rule from the colonial period that prohibited public servants from holding more than one job. In his case, he was employed as teacher while earning money as a calypsonian.

Chalkdust fought against his dismissal in song. He sang two calypsos which dealt with the issue - Reply to the Ministry and The Letter - and, as he recalled in a lecture in 2007, he was 
"immediately reinstated" when Williams said "Ah don't know what they humbugging the young man for." 62

Despite his criticisms of the prime minister and his government, Chalkdust has been a great admirer of Dr. Williams, also a historian, who inspired him to pursue his academic work.In the 2007 lecture, Chalkdust recalled that he was first introduced to Dr. Williams when in1965 the prime minister visited the European history class at the teachers' training college where he was a student. He said that at the time he (Chalkdust) "was speaking on the theme' 1848: the year of Revolution.' He listened to me for about five minutes, then tapped me on my shoulder. From that little tap, Hollis Liverpool, the historian was born, for I changed options then, read all his works and dedicated myself to the realm of history." 63

Along with a teacher's certificate and a post graduate diploma in education, Liverpool holds a B.A. in history and sociology, an M.A. in history and African history and a $\mathrm{PhD}$ in history and ethnomusicology. He has written and lectured extensively on the history of calypso and the Trinidad carnival.

His magnum opus, Rituals of Power and Rebellion: The Carnival Tradition in Trinidad and Tobago 1763-1962, (based on his $\mathrm{PhD}$ dissertation) was published in 1993.It provides a well-documented account of the origins and evolution of the carnival. He has also written From The Horse's Mouth, a social-cultural history of calypso from 1900 to 2003, published in 2004.

Chalkdust noted that with the rise of soca and other musical genres, fewer calypsonians are singing about politics but that calypso can still have a tremendous impact on public opinion.

\footnotetext{
${ }^{62}$ Liverpool, Hollis "One Caribbean: Dr. Eric Williams on Carnival, Culture and Development" 26th Annual Eric Williams Memorial lecture May 28, 2007 P.2

63 Ibid
} 
Asked whether a calypsonian can effect political change to the extent of bringing down a government, he remarked: "If the song catches on and if the song is well done, artfully done, it can happen."

Discussing unofficial censorship and self-censorship, Chalkdust, a former director of culture in the Trinidad and Tobago government, said "it is only natural when (they) calypsonians get government funding, some of them will try to be lenient with the government." He noted that the leader of a calypso tent may tell calypsonians "take out that verse or soften that verse or they (the calypsonians) may not use it at all." Chalkdust also pointed out that self-censorship can be a major problem among many young calypsonians who "sing for government and sing for (political) party and while looking for a dollar, they forget what the art form is all about."

Asked about songs which are offensive to groups in the society such as Indo-Trinidadians or women, Chalkdust pointed out that while calypsonians have always targeted different groups, "many persons get angry and sometimes they have a right to be angry when a calypso is not properly structured.

"Sometimes it is the way they (the calypsonians) composed the songs."

However, in defence of the calypsonians, Chalkdust said that many people in the society are thin-skinned.

In several of his compositions, Chalkdust noted problems facing calypso. In one of them titled Man Want to Dance, he sang about "a musical death" of calypso as people wanted to dance rather than to sit down and listen to the calypsonian. 
Commenting on Man Want to Dance, Chalkdust said that "when people come out to a soca show, a soca tent, they don't come out to listen to politics . . . there is a mood that surrounds the soca competitions and the soca songs. It 's a happy mood and noting is wrong with that. They want to dance. They want to free up. Man want to dance."

Although Chalkdust has given warning in song about problems facing calypso, his pronouncement in Man Want to Dance of a "musical death" of the art form seems exaggerated or contradictory since he does not entertain the view that "soca will kill calypso."

"There will always be calypsonians and there will always be calypso lovers because there will always be people who have sense," he remarked. 


\section{Chapter Nine}

\section{BLACK STALIN (LEROY CALLISTE)}

Leroy Calliste started singing calypso in 1959, more than five years after the death of Stalin, the leader of what was then the Soviet Union. Calliste said he knew little about the communist strongman but when fellow calypsonian Lord Blakie (Carlton Joseph) named him Black Stalin, he unquestioningly accepted the sobriquet. ${ }^{64}$

A five-time winner of the Trinidad and Tobago calypso monarch competition, Black Stalin is often referred to simply as Stalin. Asked how he prefers to be called, he replied: "I think Stalin would do."

Currently one of the four doctors ${ }^{65}$ who have worn the crown as calypso monarchs of Trinidad and Tobago, Stalin has made a name for himself as a composer and singer of political and social commentary as well as other types of songs. But in September 2014, about a month after an interview with him, undertaken as part of the research for this thesis, his singing career was placed "on hold" when he suffered a stroke. Because of speech problems resulting from the stroke, it is still uncertain when the 73-year old artiste will return to the calypso stage.

\footnotetext{
${ }^{64}$ It is not uncommon for members of the calypso fraternity to give names to newcomers to the tents. Sometimes the names would be of historical figures or newsmakers, famous or notorious.

${ }^{65}$ Black Stalin received an honorary doctorate from the University of the West Indies (UWI) in 2008. The three other doctors who wore the crown as calypso monarchs are Calypso Rose (McCartha Linda Sandy-Lewis who received an honorary doctorate from the University of Trinidad and Tobago (UTT) in 2014, the Mighty Sparrow (Slinger Francisco) who received an honorary doctorate from UWI in 1987 and Chalkdust (Hollis Liverpool) who earned a $\mathrm{PhD}$ in history and ethnomusicology from the University of Michigan in 1993.
} 
In the interview, Stalin talked about his career as a calypsonian and expressed concerns about the direction in which calypso is heading.

Although he made his debut as a calypsonian in 1959, it was in 1962 that he started singing in a calypso tent in his hometown of San Fernando in South Trinidad. By 1967, he had moved to a tent in the calypso capital of Port of Spain.

In 1979, he won, for the first time, the Trinidad and Tobago calypso monarch competition. One of his two songs at the competition titled Caribbean Unity ${ }^{66}$ is to date one of his biggest hits and one of his most controversial compositions, the message of which he claims was misunderstood. Dismissing the criticisms and charges of racism over Caribbean Unity as "unfounded," he describes the song as one "with tremendous impact."

Discussing the vexed question of race in Trinidad and Tobago's multicultural society, Stalin, an Afro-Trinidadian who was born and grew up in San Fernando, said his home town has taught him "a whole lot about the positive values of racial equality."

Reminiscing about his days as a young boy in San Fernando where he went to school with children of different races, he recalled a neighbour of Indian descent whom he referred to as Auntie Sylvia, who used to look after him when his mother was not at home.

"Ma used to leave me by Auntie Sylvia when she had to go out," said Stalin.

"I grew up in a beautiful town with some wonderful people where everybody was one. I don't recall any racial problem there," he remarked.

${ }^{66}$ Caribbean Unity is also popularly known as Caribbean Man. 
However, when asked about calypso lyrics which may be viewed as offensive to IndoTrinidadians and other groups, Stalin was quick to defend the composers' "democratic right" to self-expression.

"We live in a democracy. Somebody going to say something to offend somebody and somebody is going to say something to offend the other person. Some may love what you say and some may not love what you say. But I think this is the beauty about kaiso - that freedom to express how you feel about a particular subject...," he remarked.

Stalin concedes that "there are lines to be drawn in calypso" and that "a whole lot of people cross the line" but he is opposed to "any kind of censorship" or restraint which interferes with the creative process, It should left up to the songwriters "to censor themselves," he said.

Like Calypso Rose and several other local artistes, Stalin noted that his calypsos have been influenced by religious music." I grew up in a Shango-Baptist home and most of the vibrations in my songs really come from home - mammy and daddy singing their Shango songs," he said.

(Shango is an African religion. Forms of worship include animal sacrifice, spirit possession, drumming, dancing and chanting. The Baptist religion to which Stalin refers is the Spiritual Baptist or Shouter Baptist faith, a branch of Christianity with strong African traditions.

Complaints about the shouting, loud chanting and bell ringing at Spiritual Baptist prayer meetings led to the banning of the religion in Trinidad and Tobago by the British colonial authorities in 1917. The ban was repealed in 1951.) 
In common with many calypsonians, Stalin has had no formal musical training. But he did learn to play the steel pan, the national musical instrument of Trinidad and Tobago, and with the help of some of the giants in the calypso business, honed his skills as a composer and performer. In 1987, he was the recipient of a national award - the Humming Bird (Silver) - for his contribution to Trinidad and Tobago culture and to date has produced 14 albums. He has performed in many countries in Europe, North America and the Caribbean.

Like Gypsy (Winston Peters), the Minister of Community Development in the Trinidad and Tobago government who is widely known for his extemporaneous verses and political commentary, Stalin said he believes that a calypsonian can write a song which can "bring a government down."

"Yeah, I think he can," he declared emphatically.

However, Stalin noted that "earlier on, we (calypsonians) had much more influence on people in society than we have right now" and expressed concern about the direct involvement of calypsonians in politics." It is so crucial. This turn that calypso has made over the years where instead of singing about a situation in the country, the calypsonian gets more tied up in being a politician himself...and where calypsonians are being paid to write commercials for political parties," he said.

Stalin is also concerned about the effects of government funding of the "calypso industry." "Private investors and promoters get out of the business because it is being financed by the government. So the calypso tents are dependent on the politicians to survive," he noted.

What this means for the future of political commentary in calypso, he is not certain. 
But Dr. Stalin said that calypsonians must be ready to face the challenges ahead. 


\section{Chapter Ten}

\section{GYPSY (WINSTON PETERS)}

More than a quarter century after Gypsy (Winston Peters) first sang The Sinking Ship, he remains convinced that a calypsonian can topple a government with a song - a view shared by many leading artistes ${ }^{67}$ in the world of calypso.

"I believe that because I have done it," crowed Gypsy, a former US marine, ${ }^{68}$ who was crowned calypso monarch in 1997 and today serves as Minister of Community Development in the Trinidad and Tobago coalition government of Prime Minister Kamla Persad-Bissessar.

Gypsy, first elected to Parliament in 2000 and a former Minister of Arts and Multiculturalism, started singing calypso at the age of four in a community hall in the coastal resort and fishing district of Mayaro in South-East Trinidad where he was born. He is the second calypsonian in Trinidad and Tobago to be elected to public office ${ }^{69}$ and is widely known for his political commentaries in song as well as his extemporaneous verses for which he was unbeaten in national competitions for several years.

\footnotetext{
${ }^{67}$ Several calypsonians interviewed as part of the research for this thesis, said they believe that a calypsonian can sing a song to bring down a government.

${ }^{68}$ Winston Peters held dual citizenship. He was a citizen of both Trinidad and Tobago and the United States.

${ }^{69}$ The first calypsonian to hold elected public office in Trinidad and Tobago was Raymond Quevedo who was known as Atilla the Hun. He became a member of the Port Of Spain City Council in 1946 and of the Legislative Council of Trinidad and Tobago in 1950. Quevedo who started singing calypso publicly in 1911, died in 1962. Since Winston "Gypsy" Peters became a Member of Parliament, several calypsonians were elected to local government bodies.
} 
In an interview conducted as part of the research for this thesis, Gypsy recalls the 1986general elections in Trinidad and Tobago in which The Sinking Ship was a major campaign song for the National Alliance for Reconstruction (NAR), a coalition of political parties which ran against the People's National Movement (PNM) which had been in power for 30 years. The NAR defeated the PNM, winning 33 of the 36 seats in the Parliament.

"The Sinking Ship was in no small part responsible for the bringing down of the PNM government," Gypsy says.

Gypsy entered the political fray as a candidate for the United National Congress (UNC), a political party headed by Indo-Trinidadian lawyer Basdeo Panday who served as prime minister from 1995 to 2001. Looking back at his career in government, the calypsonian-turnedpolitician says:" Calypso is vehicle that I have used to get to where I am today. I could never forget my role as a calypsonian because a calypsonian is just as effective, if not more effective, than a politician."

As he explains: "When a calypsonian sings a song more people gravitate towards than towards a politician when he makes a speech."

However, Gypsy who won a national award (the Chaconia Medal Silver) for his contribution to the development of calypso, notes a "deterioration" in the standards of political commentary in the art form over the years since he has been in government. "It's a serious situation because at the end of the day...the calypsonian is the one who highlights the problems of the country, political or otherwise ....and there is no better person to highlight political goingson in the country than the calypsonian," he says. 
Complaining about the lack of craftsmanship in musical political commentary, Gypsy notes that "the calypsonian and the calypso writer have to be intelligent enough to understand the people they are trying to reach. The song has to be written for a particular audience."

He is not worried, though, about the growing demand for soca songs (or party music) as compared to political commentary. "I think that both soca and political commentary have their niche and I think that there is a time for everything," he remarks.

Gypsy notes that while soca has a year-round appeal "to people who want to dance and to party," the songs that are used on the election campaign "are not soca songs at all." Instead, they are the kinds of songs that will appeal to a political party and can be used as its "clarioncall," he explains.

But he points out that political commentary has a much smaller international audience than soca. According to Gypsy, calypso aficionados abroad are not interested to any great extent in listening to songs about the political situation "back home."

He does note, however, that among his compositions, The Sinking Ship has had the greatest impact. "Although it is a political song, it transcended the borders of Trinidad and Tobago and is heard in America, Canada, far off Australia and many other places," he recalls.

"Well, it's how you write your song. The metaphor in the song - The Sinking Ship - is what makes it international. The song has even been used at sporting events such as cricket and football," he adds. 
Asked about calypsos which are offensive to groups in the society such as IndoTrinidadians, women and gays, Gypsy says that there are some calypsonians who do sing such songs "from time to time" but "that is not the norm."

He also notes that interpretation can be a problem. "Lyrics are how you take them. Different people interpret things differently."

Although Trinidad and Tobago has a vibrant news media and a proliferating social media from which startling local events - the potential grist of the calypsonians' mill - are known to "go viral" before songs can even be created about such happenings, "Gypsy believes that calypso is "still as effective" today as it was twenty, thirty or forty years ago. As he sees it, each section of the news media "and even the social media" has "its own niche."

Asked whether he felt he could do more to improve the lives of the people of the country as a politician or a calypsonian, Gypsy handled the question like the seasoned politician who has mastered the art of composing verses on the spot.

The politician and the calypsonian both have "different roles to play," he replies.

As for the future of political commentary in calypso, Gypsy remains optimistic, despite the challenges. 


\section{Chapter Eleven}

\section{CALYPSO ROSE (McCARTHA LINDA SANDY-LEWIS)}

Still singing onstage at age 75, New York-based Calypso Rose (McCartha Linda SandyLewis), a breast cancer survivor, has overcome major challenges as a woman who ventured into a male-dominated arena to become the undoubted queen of the gayelle. ${ }^{70}$

Once decried in newspapers in Trinidad as the "queen of smut" because of her songs on sexual themes, Calypso Rose became the first woman to win the Trinidad and Tobago calypso monarch competition. ${ }^{71}$ She was also the first woman to win the Road March competition at the Trinidad carnival ${ }^{72}$ and was a five-time winner of the Calypso Queen competition in Trinidad. ${ }^{73}$

Looking back at her career which spans more than half a century, the Tobago-born artiste who is from a family of Spiritual Shouter Baptists, recalls the discrimination which she faced at the outset. "It didn't come from the male calypsonians. It started at home," she says.

"My father who was a preacher, told me you cannot serve two masters at the same time. What he meant was that you cannot serve God and serve the devil. When I grew up, I understood

\footnotetext{
${ }^{70}$ A gayelle is an arena or ring for cock-fighting, stickfighting or some other form of contest or confrontation.

${ }^{71}$ The competition used to be called the calypso king competition but the name was changed in 1978 when for the first time, a female contestant, Calypso Rose, was adjudged winner.

${ }^{72}$ Calypso Rose won the Road March two years in a row - 1977 and 1978.

${ }^{73}$ She was crowned calypso queen in 1972, 1973, 1974, 1977 and 1978.
} 
why he said that. Calypso originated out of African music and the white folks deemed us Africans to be the devil. So I see why my father thought that calypso music was of the devil ," she explains.

Calypso Rose who moved to Trinidad when she was nine years of age to live with an aunt, also recalls the opposition she faced from church groups when she started singing calypso professionally at age 15 .

"The church people had been calling me to meeting after meeting and asking me why I was singing calypso. They said calypso is a man's domain and that a woman should not be singing calypso," she says.

"But I fought them. I told them that God gave me the inspiration to create melody and lyrics and they could not stop me."

Calypso Rose has composed more than 800 songs - among them party songs, social commentary and gospel - and has produced more than 20 albums. She has performed in various cities in North America and the Caribbean as well as in Europe, Africa and Australia.

She is the recipient of many accolades - among them, a Trinidad and Tobago national award -the Humming Bird medal (Gold) - and an honorary doctorate from the University of the West Indies.

One of her most memorable calypsos, Fire In Meh Wire, which she first sang in 1967. has been recorded by various artistes in more than half a dozen languages. It 's about a house on fire with sexual innuendos. 
During the late 1960s, while Fire In Meh Wire got airplay on local radio stations, her songs with a gospel message - Ezekiel Coming and I am what I am - did not. As she recalls, the stations "refused to play them. The stations said ' you could not put the word of God in a calypso.'

"And now look at the Jamaican artistes. They started singing gospel after Calypso Rose opened the door. They're doing a lot of gospel in the calypso beat and the reggae beat and it's played all over the world."

In her many years as a calypsonian, Calypso Rose who started singing under the name of "Crusoe Kid," ${ }^{74}$ has witnessed the development of several new musical forms. One of them of which she remains severely critical is soca. ${ }^{75}$

The outspoken queen of the gayelle notes that instead of recording "with a band with trumpets, trombone, base guitar, keyboard and drums," some soca artistes would "lock themselves up in a room with a laptop and they making all the music out of that. They put down one rhythm and five different people singing the same rhythm with hardly any lyrics.

"We, calypsonians, are reporters in song. If we don't have the lyrics, how will we tell the public what's going on?"

Despite the rise in popularity of soca, Calypso Rose believes that political commentary in calypso still has a major impact on public opinion in Trinidad and Tobago and that a calypsonian can sing a song to bring down a government. But she is concerned about the problem of self-

\footnotetext{
${ }^{74}$ Tobago, the birthplace of Calypso Rose, is often referred to as Crusoe's or Robinson Crusoe's Isle even though another island from which Daniel Defoe is believed to have taken his inspiration in writing the novel, Robinson Crusoe, is in the Pacific Ocean.

${ }^{75}$ Although she has criticized soca, some of her most memorable calypsoes are party songs.
} 
censorship among calypsonians who avoid criticizing the government which provides major funding for calypso tents and prize money for competitions.

She says that some calypsonians who supported a political party which is out of office today "are now standing firm with the present government.

"They turn around now and wipe their slate."

She also expresses concerns about calypso lyrics which are offensive to groups such as women and people in the Indo-Trinidadian community.

"I do not know why men who were created by God and born of a woman have to castigate women in this manner," she remarks.

"The Mighty Sparrow who sang Jean and Dinah, has been knocking women left and right and I had to counteract him with a calypso," she recalls, noting that she has written several songs dealing with issues affecting women.

As for the attacks on members of the Indo-Trinidadian community, she voices her dismay. "I just don't know why these calypsonians denigrate Indians," she remarks.

Calypso Rose who has been living in New York since 1983, was diagnosed with breast cancer in 1996. In her battle against this life-threatening disease, she underwent surgery and received radiation treatment. Today she continues to wow her many fans with her energetic live performances..

As some attest :"she still has that fire in her wire." 
For Calypso Rose, who overcame discrimination, health problems and a speech impediment to become a well-loved icon, it has not been an easy road. But at this stage of the journey, she is happy that as one of the pioneers of calypso, she has been able to blaze a trail for other women

And despite the problems facing calypso, particularly in the area of political commentary, she is hopeful that the younger generation will keep the art form alive. 


\section{Chapter Twelve DENYSE PLUMMER}

Denyse Burnadette Kirline Plummer, Trinidad and Tobago's 's first blue-eyed female calypso monarch, still vividly recalls the "greeting" she received more than a quarter century ago in the city of San Fernando in South Trinidad. She was a contestant in the semi-finals of the monarch competition at Skinner Park - a venue not for the faint of heart . Many, including some calypso icons, had got the "toilet paper" treatment there. ${ }^{76}$

But what Plummer encountered when she mounted the stage was beyond anything she had bargained for. Here was a woman, considered white, who had dared not just to enter the calypso arena - still believed by many to be the preserve of people of African descent and almost entirely men - but to compete for the highest honour, which a calypsonian can receive- the monarch title.

"I got the biggest shock. Thousands in the audience with rolls of toilet paper. Many of them throwing things at me - sucked oranges, beer bottles and the toilet paper. And others holding up placards with messages such as ' Plummer go back to South Africa' and 'Next,"' she related.

"It was horrible. I had to finish two songs. With all those missiles coming at me, I continued into my second song, picking up the things they pelted and turning the missile throwing into a choreography, as if it was part of my act. I was laughing if off as the television

\footnotetext{
${ }^{76}$ In a show of disapproval, it is a common practice for the audience at Skinner Park at the annual semi-finals of the calypso monarch competition to throw rolls of toilet paper at singers onstage. Other heavier projectiles have also been thrown at singers at this venue.
} 
cameras rolled, capturing the scene for a national audience. I refused to give in to these people for them to see me cry or walk off the stage and to let them believe that they had the power to stop me...But it was very hurtful," she said.

Plummer is convinced that that "greeting" which she received from the audience at Skinner Park in 1986 had nothing to do with her singing or her songs. "It was strictly because of the colour of my skin. My mother is black. My father is white and I look like my father, though I never considered myself white," she said.

"And I became very defiant because I was born and bred in Trinidad and Tobago. As a Trinidadian, calypso is mine. Carnival is mine. The culture is mine. And I was very angry."

The following year she re-entered the monarch competition, was selected for the semifinals and with "head held high," returned to Skinner Park, still determined to pursue her dream of winning the crown. On this occasion she was not "greeted" with missiles. But she had to wait more than a decade for the calypso monarch title.

It came in 2001 when she served notice in song at the Queen's Park Savannah in Port of Spain, the venue for the annual monarch competition, that she "Nah Leaving" [Not Leaving]. ${ }^{77}$ It was a calypso in which she expressed her love for Trinidad and Tobago and declared that despite the problems in the country, she "nah leaving."

Only three other female calypsonians have won the Trinidad and Tobago monarch competition held annually since 1929 - Calypso Rose (in 1978), Singing Sandra (in 1999 and 2003) and Karen Asche in 2011. 77 "Nah leaving" was one of the two songs which won her the crown at the Trinidad and Tobago
calypso monarch competition. 
Plummer has also won both the Calypso Queen crown and the World Calypso crown four times and is the recipient of a Trinidad and Tobago national award - the Humming Bird medal (gold) - for her contribution to culture.

The 60-year old artiste who has lately switched from calypso to gospelypso, ${ }^{78}$ started her singing career while she worked as a computer operator at an insurance company in Port of Spain. Several nights a week she sang, first at a pub and later at a hotel. Her repertoire was mainly pop. Several years later, at age 34 , she made her debut on the calypso stage.

To date she has produced more than $40 \mathrm{CDs}$ of which about 30 are calypso. Some of her major hits have been "nation-building" songs and while she proudly claims calypso as part of her culture, she is concerned about its divisive effects.

"The racism in the calypsos of today is very blatant and raw. They [the calypsonians] are calling Indian names, insulting them and embarrassing them and 'dissing' them. As a result, the Indian community is not going to the tents anymore. And remember: roughly half the country is of Indian descent and the other half is of African descent. If you alienate one of these two groups, you are left with just about half."

Plummer believes that political commentary in calypso continues to have "a great effect on public opinion" in Trinidad and Tobago

"A calypsonian has the power to bring down a government, to cause a riot, to cause people to do good things, to cause people to do bad things, to cause people to hold their anger to cause people to use their anger."

${ }^{78}$ A musical genre that combines elements of traditional gospel music and lyrics and calypso rhythms. 
"Calypsonians have a great power and we have to be careful how we use it," she warned.

Discussing the development of soca and other new musical styles, Plummer said that the evolution of calypso is inevitable.

"The young people like the new styles of music. My parents thought they were rubbish. Many people may not be accustomed to those kinds of music but we cannot be too quick to criticise and to say the young people's music is rubbish," she remarked.

She acknowledged that "the songs of the young people do not have longevity" but they make "millions of people happy."

Plummer noted that with the rise of soca, "most people tend to think that calypso is dying.

"But I disagree because every year I listen to the young ones and they are singing beautiful songs. You can tell the future by listening to the children because the children are the future."

Looking back at her "greeting" at Skinner Park in 1986, Plummer said that at that time she could not understand the reaction of the audience. Now she takes a philosophical view of race relations with their "apparent contradictions.

"We will always have race problems world-wide. They will never go away. But in Trinidad and Tobago, we have all races living together. We are the most mixed up people in the world. We share office space and when we go to party, we share party space. We share carnival and we love one another." 
"But if there is a big calypso competition, the winner, in the minds of the people, would be a black calypsonian and in a chutney monarch competition, the black calypsonians and whites may enter but everybody knows that a black or white person will not be chosen as the winner. So you still have that racial tension there even though it might be disguised," she explained.

"My role was to open the gate so that people of all races can come through and sing calypso and compete," she added.

She recalled that the year after she was pelted at Skinner Park, more people of different races started to compete in calypso competitions. She also noted that that more women arenow singing calypsos." When I started singing calypso professionally there were about 15 women calypsonians. Today we have more than $250, "$ she said.

While Plummer has declared in song that she "nah leaving," she has recently announced that she has become a "born again Christian" and is leaving the calypso stage. But the artiste who grew up as a Roman Catholic, continues to sing and give praise in gospelypso. 


\section{Chapter Thirteen \\ DAVID RUDDER}

From his home in the Southern Ontario town of Ajax, David Michael Rudder, hailed as modern calypso's most innovative songwriter, remains "plugged in" to what's happening back in Port of Spain where he was born and where his career as a singer- songwriter took flight.

"I read the Trinidad news every day on-line and, of course, I am back there once or twice a month and I witness the changes in the society," says the 61-year old former calypso monarch

${ }^{79}$ who has been living in Canada since 2003.

He believes that he is at a "relative advantage" in viewing calypso developments in Trinidad from Canada, "because my nose is not up against the wall. I can look from a distance and see the entire wall."

From the distance of Ajax, Rudder believes the view does not inspire a great deal of hope for the future of one aspect of the genre. As he puts it, "a certain form of calypso is dying" - viz political commentary.

Noting the greater interest in soca or party music rather than political commentary, Rudder who has written and sung both kinds of songs, says the fact that "people are now into more party music is itself a political statement... The need to party reflects where society is at and where society is going. The life and the very existence of music will depend at the end of the day on where people will go. That is where the music will go."

${ }^{79}$ Rudder won the Trinidad and Tobago calypso monarch title in 1986. 
According to Rudder, calypso today is "more a reflection of where society is at as opposed to bringing about some kind of change in society."

"People still need to have the music in their life and what is said on top of that is just a reflection of how they feel."

As for the effectiveness of calypso as a vehicle for political commentary, he says it is"not as strong as it used to be."

At age 11, Rudder started singing in Trinidad with a band called the Inlarks, which later changed its name to The Solutions. The band played played Motown-style music. Later, in 1977, after becoming a backup singer at a calypso tent run by the legendary Lord Kitchener ${ }^{80}$ he joined Charlie's Roots, a popular local brass band, and for several years was one of its lead singers.

Unlike many present-day calypsonians, Rudder, who grew up near a panyard ${ }^{81}$ and a Shango yard ${ }^{82}$ in Belmont. Port of Spain, writes his own songs. Both the steel band and the Shango chants have had a significant influence on his music.

By1986, he had established himself as a leading singer-songwriter in the calypso world, copping both the monarch and young king titles and also winning the Road March with his song called Bahia Girl.

${ }^{80}$ The late Lord Kitchener (Aldwyn Roberts) is described as the grandmaster of calypso and the Road March king. He wrote more than 1000 calypsoes and won the Road March title a record 13 times.

${ }^{81}$ A panyard is an area where a steelband practices and where steel pans and equipment are stored.

${ }^{82}$ A Shango yard is an area where Shango worship is held. The worship may include animal sacrifice, spirit possession. drumming, dancing and chanting. 
In 1990, Hollywood beckoned. He sang Dark Secrets with Brazilian artiste Margareth Menzes in the Warner Brothers movie Wild Orchid. The song is one of several of his compositions in the movie. His music is also featured on the soundtracks of two other movies.

As an international artiste, his tours have taken him to various cities in Europe, North America, Latin America, the Caribbean and Japan.

The highly acclaimed singer-songwriter who once worked as an accounts clerk with a bus company in Trinidad, is concerned about "serious issues" affecting calypso.

According to Rudder, one major concern is the effect of "state funding of calypso tents."

"We have created a false environment through various governments. The [state] largess that goes into calypso tents has now come back to bite the people," he says.

Rudder argues that government funding for the tents results in the "lowering of standards" among certain calypsonians ." "If you know you are getting x amount of money to run your tent, you can tell a calypsonian ' look, I am going to give you five thousand dollars a week to come and sing with me' and the calypsonian does not have to have a good song. He just shows up and sings. But if the calypsonian has to sit on the bench and work on his song until hegets that one chance to sing, he takes it and the result is a better quality of work," he explains.

He notes that with government handouts, no one is driven "to write something biting or effective or to find new ways to connect with the people."

Like many other calypsonians, Rudder laments the lack of sufficient airplay of calypso on radio and television stations in Trinidad and Tobago. He complains that there are no content regulations which require the stations in the two-island state to play a stipulated percentage of 
local music and that there are growing numbers of young, talented artistes, some with degrees in music, who need an outlet for their work.

Rudder says there should be no problem passing laws that would require the stations to play a certain amount of calypso. "Why should that be a problem? I feel that part of the engine that drives Trinidad is a negative element- self-hatred. It's something deep down inside and we need to get rid of it," he remarks.

He also complains that calypso is seen in its homeland as "seasonal music."

According to Rudder, treating it as "seasonal music" has also "hindered the development of the art form because people try to cram five or six hundred songs into a two-or three-month period - the carnival season."

"While the music should be living all year round with a surge at that time [the carnival season], what we have is just a surge," he notes.

Rudder who did not give himself or accepted a sobriquet or stage name, sees himself asa "calypso artiste" rather than a calypsonian. Discussing the often hotly debated issue of calypsonian vs. calypso singer, he says he does not consider it important whether a singer writes his own material "or sings someone else's composition."

Noting that in the "old days," a lot of calypsonians wrote their own songs, he says that" over the last 30 years" or so, many of them have been singing other people's compositions.

"There are some people who write songs but cannot sing. If those songwriters give their compositions to those who have a voice, I have no problem with that. Then there are composers 
who may write something to which a singer feels a certain closeness and so the song may be suited to that particular singer," he explains.

Rudder has produced 20 albums, eight singles or EPs and one compilation. Among his more memorable songs are "Trini ${ }^{83}$ to the bone," a patriotic song, and "Rally round the West Indies," which is widely regarded as the anthem of West Indies cricket.

From his Canadian vantage point, he keeps a close watch on "events and situations well beyond the shores of Trinidad and Tobago" and many of his compositions deal with

"I write about life in general but from a Caribbean perspective, says Rudder.

${ }^{83}$ A Trini is a national of Trinidad and Tobago. 


\section{Chapter fourteen}

\section{PROPHET OF SISYPHUS}

\section{(PRESIDENT ANTHONY THOMAS AQUINAS CARMONA)}

Prophet of Sisyphus, ${ }^{84}$ better known today (in 2015) as the President of the Republic of Trinidad and Tobago, ${ }^{85}$ last appeared on the calypso stage in 1980. But he still feels a "strong bond" with the calypso fraternity and has kept in close touch with "the latest trends" in the music.

In an interview, President Anthony Thomas Aquinas Carmona, a former Trinidad and Tobago high court judge, recalls "cherished memories " of his experiences as a calypsonian going back to the time when he was at university. He also notes "deep concerns" about the present direction of the music.

Prophet of Sisyphus who made it to the semi-finals in the Trinidad and Tobago calypso monarch competition in 1980, debuted in 1974 at the Mona campus of the University of the West Indies in Jamaica. As he recalls, the only calypso contest held in Jamaica at the time was" on campus.

"Everyone was telling me that I should enter the contest. They said 'you're Trinidadian and you're supposed to know how to sing calypso.' Well, they actually won me over," he says with a chuckle.

\footnotetext{
${ }^{84}$ As a calypsonian, Anthony Thomas Aquinas Carmon took the sobriquet Prophet of Sisyphus after reading The Children of Sisyphus, an existentialist novel by Jamaican-born sociologist Orlando Patterson.

${ }^{85}$ Under the republican constitution of Trinidad and Tobago, a former British colony, the president replaced the monarch as the ceremonial head of state. Trinidad and Tobago became a republic in 1976, 14 years after the two-island state attained its independence from Britain.
} 
"So I quickly composed a song. I wrote it out on a piece of paper and though I had very little practice with the band, I went on stage. But the moment I stepped on that stage and saw the crowd, that was it. Stage fright overwhelmed me and I 'busted' somewhere in the middle of my rendition."

"Though embarrassing, it was a vital lesson in show business. Preparation is so important if you want to make it to the top," he notes.

The following year he competed again. This time he was "confident of doing better" and he won the contest.

Michael Manley was prime minister of Jamaica at the time and on campus his philosophy of democratic socialism was a major talking point.

"Significantly, with all the buzz about democratic socialism, my winning song was titled Revolution. It echoed a message of hope, peace and equality for all, regionally and internationally," says President Carmona.

After receiving his first degree, he returned to Trinidad, taught at a high school for a year and then went to Barbados to study law at the Cave Hill campus of the University of the West Indies. While there, he learned that there was to be a calypso contest on campus.

He entered again - and won with a song called Conscious Man" which dealt with political and social developments internationally and particularly in South Africa."

From the university campus in Barbados to a calypso tent in Trinidad seemed like a "natural progression" for the aspiring singer. So in 1980, while still a law student, Prophet of 
Sisyphus went for an audition at the Carnival Development Corporation (CDC) tent at the Town Hall in Port of Spain.

One Saturday morning, soon after the audition, he picked up a newspaper and saw that he was selected to sing at the $\mathrm{CDC}$ tent.

"When I saw my name in the newspaper, I started to scream with joy and when I told my sisters the news, they started screaming too. I felt a greater sense of accomplishment making it to the calypso tent than earning my first degree. Yes, I was elated when I earned my degree but this was something different. Something extra."

"Since I was still working towards my law degree, I had arranged to sing at the tent only on Thursday, Friday, Saturday and Sunday nights. On Monday mornings I would take the first flight at six o'clock back to Barbados for classes," he recalls.

"Of course, what I was paid for singing in the tent was just enough for my airfares to and from Barbados but it did not matter. I was singing for more than just the money," he says.

Prophet of Sisyphus was one of the calypsonians from the CDC tent selected for the semi-finals in the 1980 Trinidad and Tobago calypso monarch competition held at Skinner Park in San Fernando in South Trinidad.

Like many fellow calypsonians, he was apprehensive about competing in the semi-finals. Recalling his appearances ${ }^{86}$ onstage at Skinner Park, he describes them as " an emotional volcano, almost a blur, because of the intensity.

" But I got a good reception from the audience there."

${ }^{86}$ Each contestant in the semi-finals makes two appearances onstage. 
He also remembers getting tremendous support from the police band that accompanied the calypsonians."Even today, I would meet some of the members of the band and there is one love. We would greet each other with such great affection."

President Carmona's relatively short calypso career ended just before he joined the legal Trinidad and Tobago, to prosecutor at the International Criminal Tribunal for the former Republic of Yugoslavia. and then to a judge of the High Court in Trinidad and Tobago. He was later appointed a judge of the International Criminal Tribunal in The Hague where he last served before he took up the position of President of the Republic of Trinidad and Tobago.

Noting that he still considers himself a member of the calypso fraternity, President Carmona says he "listens critically" to the songs. "Sometimes while they are singing, in my mind I would compose a verse that I feel could have been added to the topic and I would hum it. As for the musical accompaniment, I might say the brass section should go like this and not like that."

Expressing his concerns about the current direction of the art form, President Carmona speaks out about "the monotony in lyrical content, in style, in music, in arrangement.

" I think that there are still excellent, creative wordsmiths or composers around but they are a diminishing breed and the minute they compose for more than one artiste, there is clear and present danger of commonality of verses, ideas, song, music, rhythms. I think that is sometimes the danger of writing for too many people.

"However, some people have great voices but don't have the composing skills. So the meeting of talent between singers and composers is something that should not be discouraged." 
President Carmona also notes his concerns about songs "which are offensive to various groups and individuals in the society.

" I think there is sometimes a lack of finesse in so many calypsos. I remember there were wordsmiths who would craft an idea, craft a song in a way that would be humorous and still critical without being offensive. That craft is becoming in short supply."

"We live in an era in which the definition of freedom of expression has evolved to the point where people feel they have a right to say any and every thing they wish, no matter how revolting and raw. Well, freedom of expression is something that requires restraint, responsibility and fairness. Freedom of expression is not about excess. What I have found in some calypsos is an attempt or rather an objective to sing in an offensive, raw manner. And there is no need for it because you can critically explore avenues by being a good wordsmith," he points out.

As Prophet of Sisyphus sees it, "the purpose of the calypso tactician is not to be offensive but to be a dynamo of change and commentary that triggers both retrospection and introspection. 


\title{
Chapter Fifteen
}

\author{
CALYPSONIANS VS. CALYPSO SINGERS \\ ...yuh cyah place jackass to run horse race \\ Excerpt from Pretender's Reminder by Mistah Shak (Selvon Noel)
}

Today (in 2015) reports abound that calypso is dying and at least one calypsonian has predicted its demise by the year $2020 .{ }^{87}$ Yet many others are not prepared to write off political commentary in calypso as a dying art, even though only a relatively few calypsonians are composing "editorials in song" and soca remains on the ascendancy.

In this chapter we will examine the controversial question of calypsonians vs. calypso singers. In so doing, we will gauge the direction in which the art form continues to move in 2015, the year when the people of Trinidad and Tobago go to the polls in general elections.

Arguably, the most important annual event on the calypso calendar is the Trinidad and Tobago monarch competition. It is held at the state-sponsored Dimanche Gras show at the Queen's Park Savannah, a cultural and sports venue in Port of Spain, on the Sunday before Ash Wednesday. ${ }^{88}$ At this competition calypso enthusiasts look forward to hearing the cream of the crop of the season's calypsos.

As in former years, there were twelve contestants, including the last year's calypso monarch, in the 2015 competition. Four were women. One of them, Karen Asche was the

\footnotetext{
${ }^{87}$ Sprangalang (Dennis Hall) made the prediction in an interview on January 20, 2015.

${ }^{88}$ Carnival celebrations in Trinidad and Tobago take place on the Monday and Tuesday before Ash Wednesday.
} 
2011calypso monarch. However, missing in this year's line-up of singers vying for the crown and a cash prize of $\$ 1,000,000$ (TT) were some of the old stagers who write their own songs. Among those absent were Chalkdust (Hollis Liverpool), Cro Cro (Weston Rawlins) and Sugar Aloes (Michael Osuna), former calypso monarchs, each of whom had appeared several times in the annual competition.

Of the 24 songs presented at the competition ${ }^{89}$ many were on political themes. This was no surprise, especially in an election year in Trinidad and Tobago, a time when local politics remains an engaging topic in the print and electronic media in the country and in everyday conversation among its citizenry.

It is to be noted that many of the calypsos including one of the two sung by Chucky (Roderick Gordon), the 2015 calypso monarch, ${ }^{90}$ were not written by the singers. In a critique of the current state of the art form, one of the contestants, Mistah Shak (Selvon Noel) reminded his audience of the growing concern about singers of calypso who do not write their own songs. This decades-old issue is currently a subject of considerable debate among calypso devotees. Some argue that as artistes continue to sing calypsos, which they do not write, the art form can become a thing of the past. Others maintain that calypsonians have been singing other people's compositions for many years and in so doing, pose no problem for the future of the music.

In his song, Pretender's Reminder, Mistah Shak recalled the late Aldric Farrell, better known as Pretender, the 1957 Trinidad and Tobago calypso monarch. Pretender was a stickler

\footnotetext{
${ }^{89}$ Each of the contestants was required to sing two songs, one in each of the two rounds of the competition.

${ }^{90}$ The Rose, a political calypso which was sung by Chucky, was written by Larry Harewood.
} 
for authentic calypso and in his song, True True Calypsonian, he said that "to be a kaisonian ${ }^{91}$ you must be a composer." In making the distinction between calypsonians and calypso singers, Mistah Shak sang as follows:

Since I small I know, Preddy ${ }^{92}$ tell me in Kaiso!

That yuh cyah place jackass to run horse race.

Even if they in de same boat

You should know yuh sheep from yuh goat,

And yuh cyah place jackass to run horse race.

Replying to "kaiso experts" who say that "in every other genre," the popular singers "are

seldom the song writers," Mistah Shak pointed out:

But that is exactly what made our kaiso so special and unique

When the singer is the author of the thing he speaks.

As for the awarding of points in the competition, Mistah Shak again explained in his song why he believed that "yuh cyah place jackass to run horse race":

'Cause when the writer and the singer happen to be two different people,

Giving the singer full lyrics points eh so sensible.

So it's easy to say jackass could reach where horse reach anyday.

But it have a great difference between ah neigh and ah bray.

That's why Preddy say

We and dem cyah be de some no way, no time no day.

Mistah Shak acknowledged that there was "always space and respect" for calypso singers but suggested that "kaiso administrators " need to find ways "to make some kinda distinction" between the calypsonians and calypso singers.

So they should explore some incentives in these competitions

\footnotetext{
${ }^{91}$ The term kaisonian is often used to refer to a calypsonian known for serious social commentary who writes and sings his own compositions.

${ }^{92}$ Pretender was affectionately called Preddy by fellow calypsonians and calypso fans.
} 
To encourage those who use their own compositions.

He went on to give warning that:

...if the current trend continues, much sooner than we think,

True calypsonians could become discouraged and extinct.

So it's easy to say jackass could reach where horse reach any day,

But it have a great difference between ah neigh and ah bray.

That's why Preddy say

We and them cyah be the same no way, no time, no day.

As to whether promoters and organizers of calypso competitions as well as calypsonians and songwriters will heed Mistah Shak's warning, he (Mistah Shak) is not optimistic. He said that it is "highly unlikely" that those persons "will willingly pay attention or take into consideration" the message of Pretender's Reminder "because the current construct is beneficial to these people, even though it may be undermining and stagnating the overall development of the art form." ${ }^{13}$

Commenting on the issue of calypsonians versus calypso singers, Louis Regis, author of The Political Calypso: True Opposition in Trinidad and Tobago 1962-1987, said in an interview that some singers who do not write their own songs but are committed to calypso can be considered "genuine calypsonians."He mentioned as a case in point the Mighty Sparrow, "a professional artiste" who has had songs specially written for him. ${ }^{94}$

He said, however, that the Mighty Sparrow cannot be placed in the same category as some calypso singers today who are not calypsonians "in the genuine sense." He explained that many of these singers who do not depend on calypso for their livelihood, buy "ready-made" songs from "a handful of people" who churn out most of the calypsos. "If these singers get lucky,

93 Interview with Mistah Shak ( Selvon Noel), June 23, 2015

94 Interview with Louis Regis December 27, 2014 
they may win an award or a prize and they do a tour but when it's over, they simply return to their jobs...So there is no kind of commitment to the art form beyond that," he noted. ${ }^{95}$

Lamenting the fact that that just a few people are writing calypsos "for pretty much the whole industry," he explained that while there are good composers, the quality [of their work] is affected because of the large numbers of songs which they turn out each year. He noted that as a result "we don't have the variety. We don't have the range of perspective. We don't have the range of rhythm. We don't have the range of narrative or commentary style. So you get a sense of 'I heard this song before."' 96

Anthony Carmona, President of the Republic of Trinidad and Tobago, who sang calypso under the sobriquet Prophet of Sisyphus and has kept in close touch with the "latest trends" in the music, also spoke of the problem of composers writing for "more than one artiste." (See chapter fourteen) In such situations "there is clear and present danger of commonality of verses, ideas, songs, music, rhythms," said the former high court judge. However, noting that "some people have great voices but don't have the composing skills," Carmona suggested that "the meeting of talent between singers and composers is something that should not be discouraged." 97

For Regis, the advancing age of the composers is also a cause for concern "I am not seeing a whole new group of songwriters. I am seeing the same old people in their 60 s and so on," he said. 98

\footnotetext{
95 Ibid

96 Ibid

${ }^{97}$ Interview with President Anthony Carmona April 23, 2015

${ }^{98}$ Interview with Louis Regis December 27, 2014
} 
One of the composers, Larry Harewood, a retired schoolteacher, said that the old issue of calypsonians versus calypso singers has now being brought "sharply into focus" by those who write and sing their own songs but that this should not cause concern about the future. Harewood who has written songs for Chucky, the current calypso monarch of Trinidad and Tobago, and other artistes, noted that in the past many composers [of calypso] were mainly unknown "ghost writers." But he said that today more composers are claiming ownership of the songs which they have written and they have produced the winning songs for calypsonians in the Trinidad and Tobago monarch competition on several occasions "in the last ten years or more." 99

In response to Mistah Shak's reference to sheep and goat in Pretender's Reminder, Harewood cited the case of the Mighty Sparrow, internationally known as the calypso king of the world. He noted that the Mighty Sparrow "started his career as a writer but soon had others writing for him...

"The question therefore remains: If a writer begins his career as a writer/singer and then subsequently morphs into singer only, is he now a 'goat'? Or if he composes the first half and the writer does the rest by finishing his song, is that performer be now called a goeep - a hybrid of goat and sheep ? What if a singer comes with an idea and the first few lines, is he to be called a 'geep'?"

In assessing the current state of calypso. Harewood said that it has evolved "but not to a great extent and not in the direction that many were expecting." As he put it, "we are no longer the 'town criers' where society depended on us for the news of the day. The news and the daily occurrences in our lives are now there for all to see in black and white with the advent of the

\footnotetext{
${ }^{99}$ Interview and personal correspondence with Larry Harewood June 3, 2015
} 
computer age. The world is now a village. Writers now, therefore, have to become more skilful in their approach to the same job that they have been doing for decades." 100

Discussing the challenges facing the art form, Harewood said: "We can no longer say the same thing the same way. We must evolve in our writing and this is where the crux of the matter lies... We can no longer tell society what it already knows. We must get our people to look deeper. Writers are now compelled to give deeper meaning to their subjects." ${ }^{101}$

Among the 2015 crop of political calypsos presented at the calypso monarch competition was The Rose sung by Chucky, the winner of the contest. In this calypso he sang about Prime Minister Kamla Persad-Bissessar who, despite criticisms about corruption in her government, has received high approval ratings in public opinion polls. The following is an excerpt from The Rose:

"Dressed up every day in a fresh set of clothes/Don't mind what is left exposed/Corruption rife and it stifling we nose/ Still the PM comes out smelling like a rose. "I

In another political calypso titled My Humble Plea, Devon Seales, the first runner-up in the monarch competition, called on the government to " go now please." None of the songs in the competition were in praise of the government.

Although one or two political calypsos stood out among the rest in the 2015 monarch competition, many may hardly remember the lyrics of most of the songs heard at the Dimanche

\footnotetext{
${ }^{100}$ Personal correspondence with Larry Harewood June 3, 2015

${ }^{101}$ Ibid
} 
Gras show. It is to be noted that there has not been much airplay of these songs on the local radio and television stations. However, this is not just because of the quality of the songs or their antigovernment messages.(See chapter six.) Except for a few radio stations which play some calypsos year round on programs dedicated to the musical genre, relatively few of the "editorials in song" are heard on the local airwaves outside of the carnival season. The Telecommunications Authority of Trinidad and Tobago, which is responsible for the licensing of local radio and television stations and regulating broadcasting services, does not have any policy regarding local content requirements for these stations. ${ }^{102}$ This continues to have negative consequences for the promotion and development of the art form.

In summary, this chapter, in assessing the current state of calypso, examined the decadesissue of calypsonians who sing their own compositions as opposed to those who sing songs written by others- an issue of growing concern and debate. On one side are those who argue that as calypsonians continue to sing songs which did not write, calypso could become a thing of the past. On the other are those who point out that while calypsonians have been singing other people's compositions for many years, in so doing, they pose no problem for the future.

In a critique of the current scene, Mistah Shak ( Selvon Noel), one of the contestants in the 2015 Trinidad and Tobago calypso monarch competition, gave warning in song that if the current trends continue, "true calypsonians" could become extinct. But Larry Harewood, a leading calypso composer, did not see the calypsonians versus calypso singers issue as a cause for concern.. He conceded, however, that the state of the art form has not evolved to a great

\footnotetext{
${ }^{102}$ Personal Correspondence with Devaki Supersad, Communications Officer, Telecommunications Authority of Trinidad and Tobago, September 25, 2014
} 
extent and not in the direction that many were expecting. Harewood suggested that with the advent of the computer age, writers have to become more skilful in their approach to the same job that they have been doing for decades." Writers are now compelled to give deeper meaning to their subjects," said the former schoolteacher. Also of concern is the lack of sufficient airplay of calypso on the local radio and television stations. 


\section{Chapter Sixteen \\ CONCLUSION}

What is calypso?

It is a feeling which comes from deep within

A tale of joy or one of suffering

It's an editorial in song

Of the life that we undergo

That and only that I know

Is true calypso.

An excerpt from What is Calypso ? by the Mighty Duke (Kelvin Pope)

Kaiso is de first music in de world,

To register a million copies sold,

But if you look and listen today,

Yuh cyah find evidence of dat greatness no way,

Is reggae like peas, hip-hop like breeze,

And kaiso is de endangered species.

An excerpt from Kaiso Blues by Mistah Shak (Selvon Noel)

The right to freedom of expression is enshrined in the constitution of the Republic of

Trinidad and Tobago ${ }^{103}$ and today calypsonians in the two-island state no longer have to contend with the repressive censorship measures of the colonial past. ${ }^{104}$ No longer are they required to submit the texts of their calypsos to a high-ranking police official who would decide whether they would be allowed to sing their lyrics at a public performance. No longer are calypso tents "supervised" by police officials who, with notebooks at the ready, would scribble in shorthand the lyrics of questionable calypsos which may not have been submitted beforehand for scrutiny. No longer do they feel the chill of colonial officialdom as tell their stories in rhythm and rhyme.

\footnotetext{
${ }^{103}$ Trinidad and Tobago which attained political independence from Britain in 1962, became a republic in 1976.

${ }^{104}$ Official censorship of calypso under the Theatres and Dance Halls Ordinance was in effect from 1934 until 1951.
} 
Yet, while calypsonians may now appear to enjoy greater freedom in presenting their "editorials in song" than during the period of official censorship, there are other restraints. What were regarded as the independent voices have at times been hushed not by legislation but by what this thesis describes as unofficial censorship as well as self-censorship.

With respect to unofficial censorship, local radio and television stations and calypso tents play a significant role. These broadcasting stations have kept certain lyrics off the air and given little airplay to others. ${ }^{105}$ For example, Congo Man, a popular calypso about cannibalism with sexual innuendos, which was sung by the Mighty Sparrow in 1965, was banned for several years from the local airwaves. Another calypso which was denied airplay by a local radio and television station, though for a relatively short period, was The Law Is An Ass, sung in 1979 by Short Pants (Llewellyn McIntosh). In this calypso, Short Pants criticized the country's justice system. Calypso tents, which receive state funding, have at times tightened their controls on some singers of political or politically partisan songs or those considered racially offensive. In one recent case, a calypsonian known onstage as Watchman (Roger Mohammed) was not permitted to sing his composition, titled False Papers, at one of the calypso tents in Port of Spain because it was considered racially offensive. ${ }^{106}$ As for self-censorship, many of its practitioners are calypsonians who are known supporters of the People's National Movement (PNM) who have forfeited their independence as political commentators by avoiding criticisms of the

\footnotetext{
${ }^{105}$ While political commentary in calypso has not been banned from the local airwaves, calypso in general receives relatively little airplay on most of the radio stations in Trinidad and Tobago as compared to American popular music.There are a few local stations which broadcast regular programs dedicated to calypso.

${ }^{106}$ Watchman was allowed to sing False Papers at another tent which did not receive government funding. That tent was in operation for a short time during the carnival season in 2015.
} 
government when the PNM is in power. ${ }^{107}$ Also, calypsonians who are hired to sing at political events or to do radio and television commercials for a particular party are not likely to criticize that party in their songs. Some, as Sugar Aloes notes, out of fear of victimization, have steered clear of political commentary. ${ }^{108}$

The restraints imposed by both unofficial and self-censorship are a growing concern for the survival of calypso as a vehicle for political commentary, already severely impacted by soca or party music which itself developed from calypso in the 1970s. With the rise in soca, there has been a decline in political calypso. As Chalkdust (Hollis Liverpool) declares in song, Man want to dance. ${ }^{109}$

In assessing calypso as a vehicle for political commentary, most of the calypsonians surveyed as part of the research for this thesis indicated that despite the challenges facing the art form, it still has an effect on public opinion in Trinidad and Tobago. Undoubtedly, it raises the consciousness of people in the society about a range of issues presented. But Winston Peters, the calypsonian-politician who sings under the name of Gypsy, went further to claim that calypso itself can effect change to the extent of bringing down a government. In his song titled Respect the Calypsonian, Peters declared: "I could write a song to make government strong/I could write a song to bring government down."

Peters who first sang that calypso in 1988, two years before he became a Member of

\footnotetext{
107 Since 1956 when the PNM won general elections in Trinidad and Tobago for the first time, it has held power for more than 40 years.

${ }^{108}$ Interview with Sugar Aloes (Michael Osuna), August 9, 2014

${ }^{109}$ In his song titled Man want to dance,( circum 1984), Chalkdust (Hollis Liverpool)

pronounces the " musical death" of calypso, noting that people want to dance rather than sit and listen to calypso.
} 
Parliament, still believes that a calypsonian can topple a government with a song. ${ }^{110} \mathrm{He}$ claims that he himself did so in 1986 with his calypso titled The Sinking Ship, which became one of the campaign songs of the National Alliance for Reconstruction, a coalition of political parties that defeated the ruling People's National Movement (PNM) in general elections that year. ${ }^{111}$

In his book, The Political Calypso: True Opposition in Trinidad and Tobago 1962-1987, Louis Regis acknowledges that when the PNM was "swept from office in 1986 it was to the tune of Gypsy's The Sinking Ship (1986) and Deple's ${ }^{112}$ Vote Dem Out (1986)." But, he writes:

"One hesitates to declare that those two calypsos were responsible for the PNM's defeat...it seems safer to conclude that while the calypsonian contributes to the legitimisation and de-legitimisation process, he [sic] may not necessarily make the difference in national politics." (Regis 1999: $\mathrm{x}$ )

Calypsonians were not hesitant on this point, however. Most of them who were interviewed, agreed with Gypsy that a calypso can in fact bring down a government. One notable exception was David Rudder, the 1986 Trinidad and Tobago calypso monarch. He took the position that a calypsonian may sing a political commentary reflecting a particular mood in the

${ }^{110}$ Interview with Winston Peters (Gypsy), September 3, 2014

111 In a landslide victory, the National Alliance for Reconstruction defeated the People's National Movement which had been in power for 30 years, winning 33 of the 36 seats in the Trinidad and Tobago House of Representatives.

${ }^{112}$ Deple is the sobriquet of calypsonian Tyrone Hernandez 
country - a mood which may lead to the fall of a government - but that the calypso itself may not be responsible for bringing down the government. ${ }^{113}$ (See chapter thirteen)

Both Rudder and Regis seem to have made an accurate appraisal of the situation. While many calypsonians may have convinced themselves that it is possible for an "editorial in song" to topple a government, or more specifically, the government of Trinidad and Tobago, their views on this subject seem highly exaggerated. There is no clear evidence that this has ever happened, despite the claims by Gypsy that his outstanding political calypso, The Sinking Ship, brought down the PNM government in 1986.

In multicultural Trinidad and Tobago, calypso is widely regarded as a national art form. However, it is also perceived as an expression of the culture of people of African descent, one of the two major racial groups in the country, the other being people of Indian descent.

In her book, The Caribbean Postcolonial: Social Equality, Post-Nationalism andCultural Hybridity, Shalini Puri notes that in the Caribbean the belief in "the existence of distinct races with clearly distinguishable racial attitudes and characteristics raises pressing questions for Trinidadian nationalism ... Which races are included under the sign 'Trinidadian' and how do they compete for inclusion? How can the opposing characteristics of African and Indian be reconciled as 'Trinidadian' ? How, in short, are racial character and national character be reconciled?" (Puri 2004: 174)

Puri points out that "the cultural centrality of calypso in Trinidad gives its construction of race wide currency and particular significance" and that "its prominence in Carnival has also given it a special role in the construction of identities and national memory." She also poses a

${ }^{113}$ Interview with David Rudder, August 18, 2014 
pertinent question in respect to identity and race: "What does it suggest about the place of IndoTrinidadians in the national imaginary that calypso has been seen as simultaneously AfroTrinidadian and national?" (Puri 2004: 183)

She notes that the importance of stereotypes in calypso, combined with the racialization of politics in postcolonial Trinidad has resulted "in a situation in which stereotypes form the bedrock of public racial discourse" and that "what these stereotypes produce for dominant cultural national discourse is the fiction of a seamless and monolithic racial community with common interests, pitted against another seamless and monolithic racial community with common interests." Puri 2004: 183)

Many calypsos have promoted negative stereotypes of people of Indian descent and have denigrated women. As Regis points out in his book on the political calypso, "all but one of the major calypso controversies since independence ${ }^{114}$ have had to do with race relations" and "several songs have been condemned as being disrespectful, divisive, insulting, mischievous, misleading, prejudicial, prejudiced, racial, racist and or all of the above." (Regis 1999 xi) With respect to the gender issue, Gordon Rohlehr states in Calypso \& Society in Pre-Independence Trinidad that "it was assumed in calypso that women were naturally fickle and unfaithful" and that "the female coping strategy of having several spouses over a period of time, some of whom might help finance a relationship. reinforces the stereotype of the naturally promiscuous female...." (Rohlehr 1990: 222)

Among calypsonians who were interviewed, there was considerable waffling by many male artistes on the issue of racially offensive songs and those that were offensive to women. For

114 Regis's book deals with the period from Trinidad and Tobago's independence in 1962 to 1987. 
example, Black Stalin (Leroy Calliste) talks about the calypsonians' democratic right to say something about someone, even though it may be offensive to that person and suggests that it should be left up to the songwriters "to censor themselves." ${ }^{115}$ (See chapter eight) Gypsy (Winston Peters) states "lyrics are how you take them. Different people interpret things differently." ${ }^{116}$ (See chapter ten)

However, Calypso Rose (McCartha Linda Sandy-Lewis), the 1978 Trinidad and Tobago calypso monarch whose career onstage spans more than half a century, notes her concerns about lyrics which are offensive to women. She says: "I do not know why men who were created by God and born of a woman have to castigate women in this manner." About attacks in song on members of the Indian community, she also expresses her dismay. "I don't know why these calypsonians denigrate Indians," she remarks. ${ }^{117}$ (See chapter eleven)

Another female calypsonian, Denyse Plummer, the 2001 Trinidad and Tobago calypso monarch, speaks out about the divisive effects of calypso. Plummer who is considered white ${ }^{118}$ and was pelted with sucked oranges, beer bottles and toilet paper when she first sang at the semifinals of the monarch competition in 1986, says "the racism in the calypsos of today is very blatant and raw. They [the calypsonians] are calling Indians names, insulting them and embarrassing them and 'dissing' them." ${ }^{119}$ (See chapter twelve)

Anthony Carmona, President of Trinidad and Tobago and a semi-finalist in the country's 1980 calypso monarch competition, also notes his concerns about songs "which are offensive to

\footnotetext{
${ }^{115}$ Interview with Leroy Calliste (Black Stalin) August 3,2014

${ }^{116}$ Interview with Winston Peters ( Gypsy) September 3, 2014

${ }^{117}$ Interview with McCarta Linda Sandy-Lewis (Calypso Rose) August 13, 2014

${ }^{118}$ Plummer is of mixed race. Her father is white and her mother is black.

119 Interview with Denyse Plummer, September 15, 2014
} 
various groups and individuals in the society." As he sees it, "there is sometimes a lack of finesse in so many calypsos." He recalls that there were wordsmiths who would craft a song "in a way that would be humorous and still critical without being offensive. That craft is becoming in short supply." ${ }^{120}$ (See chapter fifteen)

Discussing freedom of expression which some calypsonians cite in defence of their songs which offend various groups, President Carmona, a former high court judge, notes that the definition [of freedom of expression] has evolved to the point " where people feel they have a right to say any and every thing they wish, no matter how revolting and raw.

"Freedom of expression is something that requires restraint, responsibility and fairness... What I have found in some calypsos is an attempt or rather an objective to sing in an offensive, raw manner. And there is no need for it because you can critically explore avenues by being a good wordsmith." (See chapter fifteen)

Fewer songs which are racially offensive or insulting to women are now heard at public performances and in a contested cultural environment, as calypso tents tighten their control on lyrics considered offensive, the presence of more women on the calypso stage is seen as a positive development. ${ }^{121}$ Although outnumbered by men, female calypsonians are raising their voices against denigration and oppression ${ }^{122}$ and several of them have been crowned calypso monarch of Trinidad and Tobago in the annual competition.

120 Interview with President Anthony Carmona, April 23, 2015

${ }^{121}$ In the 2015 Trinidad and Tobago calypso monarch competition, no fewer than four of the twelve contestants were women. Among them was Karen Asche, the 2011 calypso monarch.

${ }^{122}$ Female calypsonians also sing on a wide range of other issues. 
Ironically, while the constitution of Trinidad and Tobago provides for the freedom of expression for which calypsonians fought in the colonial period, the 21 st century has not witnessed so far the full flowering of political commentary in song. This thesis takes the position that if there were a golden age of political and social commentary in calypso in Trinidad and Tobago, it was during the colonial period when censorship laws were in effect and calypsonians outwitted and defied the authorities in order to deliver their "editorials in song" in the calypso tents - a time when the creative talents of the composers blossomed in spite of the harsh colonial environment of official restraint.

Writing about the colonial period in Kaiso! The Trinidad Calypso, Keith Warner quotes Albert Gomes, a politician "of importance in the struggle against British colonialism" and an "early champion of the calypso as a vehicle for social and political commentary" as describing calypso as "the most effective political weapon in Trinidad." (Warner 1999: 69) He further quotes Gomes as saying that "people go to the Calypso tent to be entertained. What politician, who must harangue from the rostrum, can boast of a better opportunity for influencing people's mind ? The fact that the tents are so sedulously supervised by the police reveals the extent to which the Calypso singers influence political thought." (Warner 1999: 69)

Today the calypso tents are not "supervised by the police" as in the time of Albert Gomes. It is questionable whether calypso is "the most effective political weapon in Trinidad" in the digital age and to what extent it influences political thought. Undoubtedly, calypsonians in the two-island republic do appear to enjoy freedom of expression in large measure. However, calypso as a vehicle for political commentary continues to face the challenges of unofficial censorship and self-censorship. 
In assessing its future, the decades-old issue of calypsonian versus calypso singer has recently come to the fore. There is growing concern about singers of calypsos who do not write their own songs. Some believe that an authentic calypsonian writes and sings his own compositions and argue that as artistes continue to sing calypsos which they do not write, the musical style can become a thing of the past. Others point out that for many years, calypsonians have been singing other people's compositions and in so doing, pose no problem to the art form. (See chapter fifteen)

Mistah Shak ( Selvon Noel), one of the contestants in the 2015 calypso monarch competition, raised the issue in his song titled Pretender's Reminder. ${ }^{123} \mathrm{He}$ warned his audience at the competition that:

...if the current trend continues, much sooner than we think, True calypsonians would become discouraged and extinct.

However, Mistah Shak is not optimistic that promoters and organizers of calypso competitions as well as calypsonians and songwriters will heed his warning "because the current construct is beneficial to these people, even though it may be undermining and stagnating the overall development of the art form." ${ }^{124}$

Commenting on the issue of calypsonians versus calypso singers, Louis Regis said that some singers who do not write their own songs but are committed to calypso can be considered "genuine calypsonians." He noted, however, that just a few people are writing calypsos "for pretty much the whole industry" and that " while there are good composers, the quality [of their

${ }^{123}$ Aldric Farrell, better known as Pretender, said in his song True True Calypsonian that to be a calypsonian "you must be a composer."

${ }^{124}$ Interview with Mistah Shak (Selvon Noel), June 23, 2015 
work] is affected because of the large numbers of songs which they turn outeach year." ${ }^{125}$ (See chapter fifteen)

President Carmona also spoke about composers writing for "more than one artiste." He explained that in such situations "there is clear and present danger of commonality of verses, ideas, songs, music, rhythms." However noting "some people have great voices but don't have the composing skills," he suggested that "the meeting of talent between singers and composers is something that should not be discouraged."126 (See chapter fourteen)

Composer Larry Harewood dismisses the calypsonians versus calypso singers discussion as a cause for concern. What does concern Harewood, who has written calypsos for Chucky (Roderick Gordon), the 2015 Trinidad and Tobago calypso monarch, and several other artistes, is "the changing technology of the computer age." ${ }^{127}$ (Chapter fifteen)

"We are no longer the town criers where society depended on us for the news of the day. The news and the daily occurrences in our lives are now there for all to see in black and white with the advent of the computer age...We can no longer say the same thing the same way. We must evolve in our writing and this is where the crux of the matter lies." he said. ${ }^{128}$ (Chapter fifteen)

While calypso has often been described as the poor man's newspaper, it is hardly an apt description in the 21 st century, given its evolution and the technological changes in mass communication. What then of the future?

125 Interview with Louis Regis, December 27, 2014

126 Interview with President Anthony Carmona, April 23, 2015

127 Personal correspondence with Larry Harewood, June 3, 20154

128 Ibid 
Of considerable discussion lately has been is the question of whether calypso as a vehicle for political commentary is dead or dying, as some commentators suggest. Singer and comedian Sprangalang (Dennis Hall) has predicted that by 2020 there will be "no such thing as calypso" 129 (See chapter six) and the Mighty Sparrow (Slinger Francisco), when asked whether political commentary in calypso was a dying art, said: "I would think so. It looks that way." ${ }^{130}$ (See chapter seven) However, many others remain optimistic about the future, despite the challenges calypso faces. University lecturer, historian and calypsonian Chalkdust (Hollis Liverpool) declared in a recent interview that "there will always be calypsonians and there will always be calypso..."131 (See chapter eight)

Like the pawi, ${ }^{132}$ calypso as a vehicle for political commentary remains an endangered species It has been an endangered species from the early days of its development on the slave plantations. Compared to soca, it is certainly in decline. However, reports that it is dead or dying seem grossly inaccurate. Whenever the society in which it was born finds itself in danger, whether from attempted insurrection or as result of some other major crisis, it is through calypso that it still voices some of its deepest concerns.

${ }^{129}$ Interview with Sprangalang (Dennis Hall), January 20, 2015

${ }^{130}$ Interview with the Mighty Sparrow (Slinger Francisco), November 24,2014

131 Interview with Chalkdust (Hollis Liverpool), August 8, 2014,

132 The pawi,or the Trinidad piping guan (pipile pipile), a bird found only in Trinidad, is on the endangered species list. 


\section{REFERENCES}

\section{BOOKS/DISSERTATION/LECTURE}

Birth, Kevin K . Bacchanalian Sentiments Durham, North Carolina: Duke University Press, 2008

Brereton, Bridget Race Relations in Colonial Trinidad 1870-1900 New York: Cambridge University Press, 1979

Constance, Zeno Obiageli Tassa, Chutney \& Soca: The East Indian Contribution To The Calypso San Fernando, Trinidad: Zeno Obiageli Constance,1991

de Leon, Rafael (The Roaring Lion) Calypso from France to Trinidad: 800 Years of History San Juan, Trinidad : Rafael de Leon, (no date)

Elder, Jacob Delworth Evolution of the Traditional Calypso of Trinidad and Tobago: A Sociohistorical Analysis of Song Change Ph.D. Dissertation, University of Pennsylvania, 1966

Guilbault, Joycelyne Governing Sound: The cultural politics of Trinidad's Carnival Musics Chicago \& London: The University of Chicago Press,2007 
Hall, Stuart (Ed.) Representation: Cultural Representations and Signifying Practices London: Sage Publications Ltd.,1997

Hill, Errol The Trinidad Carnival: Mandate for a National Theatre London: New Beacon Books Ltd.,1997

Liverpool, Hollis Rituals of Power \& Rebellion: The Carnival Tradition in Trinidad and Tobago -1763-196 Chicago: Research Associates School Times Publications/Front Line Distribution Int'l Inc., 2001

One Caribbean: Dr. Eric Williams on Carnival, Culture and Development Port of Spain, Trinidad : 26th Annual Eric Williams Memorial Lecture, May 28, 2007 Naipaul, Vidia S.The Middle Passage: Impressions of Five Societies - British, French and Dutch - in the West Indies and South America New York: Vintage Books, 1981

Puri, Shalini The Caribbean Postcolonial: Social Equality, Post-Nationalism, and Cultural Hybridity: New York: Palgrave Macmillian,2004

Quevedo, Raymond (Atilla the Hun) Atilla's Kaiso: A short history of Trinidad calypso St. Augustine, Trinidad: Department of Extra Mural Studies, University of the West Indies, 1983

Regis, Louis The Political Calypso: True Opposition in Trinidad and Tobago 1962-1967 Jamaica: The Press University of the West Indies,1999

Rohlehr, Gordon Calypso \& Society in Pre-Independence Trinidad Port of Spain: Gordon Rohlehr, 1990 
Warner, Keith Q. Kaiso!The Trinidad Calypso: A study of calypso as oral literature Pueblo, Colorado: Passeggita Press Inc.,1999

Williams, Eric Inward Hunger: the Education of a Prime Minister Chicago: University of Chicago Press, 1969

The History of the People of Trinidad and Tobago London: Andre Deutsch, 1964

Winer, Lise (ed.) Dictionary of the English/Creole of Trinidad \& Tobago Montreal \& Kingston: McGill-Queen's University Press,2009

\section{ARTICLES FROM NEWSPAPERS AND JOURNALS}

Blood, Peter Ray "More blows for Sugar Aloes over Bodyguard Snub" Trinidad Guardian January 16, 2014 P.3A

Dean, Darryl "Are rebels still a threat in Trinidad?" Toronto Star May 8, 1992 P.15A

Joseph, Terry "Calypso Muzzling Itself" Trinidad Express November 22, 2015 P. 16

Kowlessar, Geisha "Aloes rejects 'race' song" Trinidad Guardian January 15, 2014 P.3A

Pearse, Andrew "Carnival in Nineteenth Century Trinidad" Caribbean Quarterly 4/3\&4 (March-June 1956):180 
Pearse, Andrew "Mittoo Sampson On Calypso Legends Of The Nineteenth Century"

Caribbean Quarterly 4/ $3 \& 4$ (March-June 1956): 254

\section{PERSONS INTERVIEWED}

Anthony Thomas Aquinas Carmona (Prophet of Sisyphus), President of Trinidad and Tobago and semi-finalist in the 1980 Trinidad and Tobago calypso monarch competition

Basdeo Panday, former prime minister of Trinidad and Tobago

Slinger Francisco (The Mighty Sparrow), calypsonian

Leroy Calliste (Black Stalin), calypsonian

Winston Peters (Gypsy), calypsonian and government minister

David Rudder, calypsonian

Hollis Liverpool (Chalkdust), calypsonian and university lecturer

McCartha Linda Sandy-Lewis (Calypso Rose), calypsonian

Michael Osouna (Sugar Aloes), calypsonian

Weston Rawlins (Cro Cro), calypsonian

Denyse Plummer, calypsonian

Roger Mohammed (Bodyguard), calypsonian

Drupatee Ramgoonai, calypsonian

Dennis Hall (Sprangalang), calypsonian and comedian

Selvon Noel (Mistah Shak), calypsonian

Edwin Ayoung (Crazy), calypsonian

Winston Scarborough (De Original De Fosto Himself), calypsonian

Samraj Jaimungal (Rikki Jai), chutney soca artiste

Larry Harewood, songwriter 
Gordon Rohlehr, retired professor of West Indian literature and calypso researcher Louis Regis, university lecturer and calypso researcher 


\title{
APPENDIX
}

\author{
PORTRAIT OF TRINIDAD
}

Portrait of Trinidad, first sung in 1965 by the Mighty Sniper (Mervyn Hodge),remains an immensely popular calypso.It is often described as the "unofficial national anthem of Trinidad and Tobago."

Trinidad is my land

And of it I am proud and glad

But Ah cyar understand

Why some people does talk it bad.

All ah dem whey running dey mout

Doh know wha' dey talking 'bout.

They will paint here black every day

And the right things they will never say.

\section{Chorus}

Like our sportsmen being rated among the best

Our scholars have sat and passed every test

And they rank along the best

And then our Pitch Lake is the greatest one of its kind

Our sugar and oil is really refined.

So you see, friends, this is a real King Solomon's Mine

They does talk some nonesense

Meh ent know what they doing it for

'Bout so much violence

Man, you would swear that we fighting war.

We have we delinquents to face

But just like any other place.

Look the things they does say 'bout here

Is really too much for me to bear.

Chorus

Because my people are daily making progress

Without any form of stupidness

And in this way we must gain success

For when we moving, we all move as one body 
No bickering between you and me

And our policy stands for racial equality.

Now when a stranger

Spending a little time in this lovely isle

Every day you see him, he always have a hearty smile

And when his time is up to depart

He would say with pride in his heart 'I'll be back you could bet yuh life

And if Ah don't come back, Ah go send mih wife.

\section{Chorus}

Now let me tell you, he really want her to come

To drink a rum and have plenty fun

In this great island in the sun

For Trinidadians, as foreigners do recall,

It doesn't matter whether big or small

Or if you rich or poor friends, we cater for one and all.

So all ah dem who talking

They either drunk or they staring mad

Or maybe they forgetting

Mr. Universe belong to Trinidad.

We have men with talent and skill

With high hopes of improving still

And if you think all this is a lie

The Mighty Sniper go show you why.

\section{Chorus}

Now our steelband is the best talent in the world.

By calypsos our stories are told

With its rhythm to touch your soul.

So Trinidad, this lovely land of my birth

Small but overwhelming in worth

And as you know, Carnival is the greatest frolic on earth. 


\section{THE SINKING SHIP}

The Sinking Ship is an outstanding political calypso which became a campaign song for the National Alliance for Reconstruction, a coalition of political parties in Trinidad and Tobago which won the general elections in 1986. It was composed and sung by Gypsy (Winston Peters) who became a Member of Parliament and is currently Trinidad and Tobago's Minister of Community Government.

The 'Trinidad', a luxury liner

Sailing the Caribbean Sea

With an old captain named Eric Williams

For years sailed smooth and free

But sadly Eric Williams passed away

The ship hit rough water that day

Somebody turn the bridge over

To a captain named Chambers

Mid blood crawl

Thing start to fall

Hold mih head when a sailor bawl

Captain, the ship is sinking!

Captain, the seas are rough

We gas tank almost empty

No electricity

We oil pressure reading low

Shall we abandon ship

Or shall we stay on it

And perish slow

We don't know, we don't know

Captain, you tell me what to do

(ii) The 'Trinidad', oh she was a beauty

With wealth that few surpassed

And in her days she sailed majestically

There were few in her class

Faithfully she fulfilled her sailors' need

Some were overpowered by greed

And so they pilfered slow

Some took by bulk and go

Now she looks dull, she's at a lull

She can barely sit on her hull 
(iii) The 'Trinidad', in her days of sailing She was a friend to one and all.

She never once hesitated

To answer all SOS calls

And yes, well she always did her best

To help out those in distress.

Now it is so sad to see she's in difficulty

Some she helped jeer, some of them cheer

And sarcastically declare:

(iv) Now there is a lot of finger pointing.

Suspicion is running strong.

Who's to be blamed for all her failures?

Who's to be blamed for doing her wrong?

But please remember I'm warning you:

For thirty years she had the same crew

Who holds the keys to her vault.

So we know who is at fault.

Now it's up to you, it's up to me

To make her worthy to go back to sea. 


\section{CONGO MAN}

Banned for several years from airplay on radio stations in Trinidad, Congo Man, was first sung by the Mighty Sparrow in 1965.It is a popular calypso about cannibalism with sexual innuendos.

Two white women travelling through Africa

Find themselves in the hands of a cannibal headhunter.

He cook up one and he eat one raw;

They taste so good he wanted more.

Me want more more more...me want more.

Chorus

I envy the Congo Man

Ah wish ah coulda go and shake he hand.

He eat until he stomach upset

And I never eat ah white meat yet.

Peeping through the bushes to see what's taking place

There I saw the Congo going to take a taste.

He open he eye and start to grin,

Rubbing he belly and mumbling

Me want more more more more...me want more.

He tied them up and put them to lay down on the ground.

Light up the fire and started dancing round and round.

One of the women started to beg.

He bite she on she chest; he bite she on she leg.

More more more more more...he eat she raw

The next one started screaming with all the voice she got. He lift she up and put she inside a big, big pot.

Ah mean the water was warm; she started to wiggle;

The Congo started to laugh and giggle. 


\section{NETTY, NETTY}

Netty, Netty, a calypso about a prostitute, composed by the Roaring Lion (Rafael de Leon), was banned by the Trinidad and Tobago Commissioner of Police in 1936 and an entire shipment of records of the song was dumped in Port of Spain harbour.The banning of the calypso did not diminish its popularity.In 1937, it was the Road March at the Trinidad Carnival.

If you can't stand the digging, give me back my shilling. If you can't stand the digging, give me back my shilling. Netty, Netty, give me de ting dat you have in your belly. Netty, Netty, give me de ting dat you have in your belly.

Chorus

Christmas night I nearly died wid laugh, Lying in de bed wid a brown skin craft. Christmas night I nearly died wid laugh, Lying in bed with a brown skin craft. I heard a gin bottle with a wicked roll Tambu bamboo nearly make me lose control.

The craft on the bed was very still. She heard the gin bottle and she got a thrill.

She said, wake up, Lion, let's make our name.

The tamboo bamboo addling me brain.

She said I ain't care nothing at all.

I go wuk mehself till meh nightie fall.

Well the craft caught a vaps and she start to dance.

She said darling, come leh me take a chance.

I said woman stop your stupidness

You always calling me for foolishness.

She said she ain't care nothing at all.

She jump in the road and she nightie fall. 